\title{
RESIDENTIAL WATER CONSERVATION: A CROSS COMPARATIVE ANALYSIS
}

\author{
A Thesis \\ presented to \\ the faculty of California Polytechnic State University, \\ San Luis Obispo
}

\begin{abstract}
In Partial Fulfillment
of the Requirements for the Degree

Master of Science in Architecture
\end{abstract}

by

Jeffrey Cook

October 2011 


\section{(C)2011 \\ Jeffrey Cook \\ ALL RIGHTS RESERVED}




\section{COMMITEE MEMBERSHIP}

TITLE: $\quad$ Residential Water Conservation: A Cross Comparative Analysis

AUTHOR: Jeffrey Cook

DATE SUBMITED: $\quad$ October 2011

COMMITEE CHAIR: James Doerfler, Professor, Associate Department Head

COMMITEE MEMBER: Scott Kelting, Professor

COMMITEE MEMBER: Sandra Stannard, Professor 


\section{ABSTRACT \\ Residential Water Conservation: A Cross Comparative Analysis Jeffrey Cook}

This thesis will explore different water conservation strategies and systems in the residential home, using the city of Irvine as a basis. The thesis will compare the financial implications between the different systems and as a return on investment. The analysis will also account for ecological and social implications on the occupants, in particular their standard of living and lifestyle changes. The thesis will explore the ability to conserve water in new residential construction and will provide a sustainable and conscientious schematic water design for the particular area of concern.

This thesis will act as a preliminary case study for a water system in a California residential home. It will address the entire lifecycle of water after it arrives on site, to the use of the water and eventual expenditure. A comprehensive design solution will be proposed, based on the body of knowledge in the field and the research findings. The design will also evaluate the alternatives of different systems, in terms of: catchment, treatment, filtering, reuse, and for returning the used water back into nature (sometimes through a municipal system). It is expected that the proposed system will inform the occupants of their water usage, and simultaneously control and reduce water usage levels.

As part of the final proposal, a detailed analysis will be provided of the entire water system. It will involve a critical analysis of existing systems as well as the application of the new design. The thesis will highlight how decisions were made based on the criteria that would affect the occupants, allowing for future adaptations of the 
solution to projects or case studies with different standards. The end-product of the research will be a baseline development that can be further explored as technology and demand change in the future, and when on-site water systems become more abundant and better understood. 


\section{TABLE OF CONTENTS}

Page

LIST OF TABLES

vii

LIST OF FIGURES

viii

Chapter

I. INTRODUCTION

II. RESIDENTIAL SELECTION

III. ANALYSIS RATING CRITERIA

IV. UNDERSTANDING WATER

V. APPLIANCE LEVEL SYSTEMS

VI. GREY WATER LEVEL SYSTEMS

VII. WATER CATCHMENT

VIII. ON-SITE WATER TREATMENT

IX. CONCLUSION

X. APPENDIX

XI. BIBLIOGRAPHY 


\section{LIST OF TABLES}

Table

Page 
1. 2005 U.S. Census Bureau for Irvine and California

2. Irvine Water Cost Structure

3. Predicted Water Prices

4. Appliance Level Contaminants and Needs

5. Appliance Level: Faucets

6. Appliance Level: Showers

7. Appliance Level: Toilets

8. Appliance Level: Landscaping 35

9. Grey Water: Potable Calculation

10. Grey Water: Landscaping

11. Grey Water: Toilets

12. Grey Water: Summary

13. Catchment: To Internal Grey

14. Black Water: Composting Toilets

15. Black Water: Living Machine

16. Black Water: Grey Mechanical

17. Summary

18. Appendix: Appliance

19. Appendix: Appliance Existing

20. Appendix: Overall

21. Appendix: Alternate ROI 


\section{LIST OF FIGURES}

Figure

1. Distribution of Earth's Water 4

$\begin{array}{lll}\text { 2. } & \text { U.S. Seasonal Drought Outlook } & 6\end{array}$

3. 2005 Withdrawals by Category 8

4. 2005 Withdrawals by Category, Arranged by State 12

5. Irvine Temperature, Humidity, Precipitation 15

$\begin{array}{ll}\text { 6. IRWD's Water Supply Portfolio } & 16\end{array}$

$\begin{array}{ll}\text { 7. New Home Water Use } & 10\end{array}$

8. House Floor Plan 20

9. Appliance Level: Summary 36

10. Appliance Level: Future Value 37

11. Appliance Level: 30 Year ROI 37

12. Appliance Level: Original and Appliance Level Water Usage 38

13. Grey Water: Summary 45

14. Grey Water: Landscaping 30 Year ROI 46

15. Grey Water: Potable and Grey Water Breakdown 47

16. Catchment: Summary 54

17. Black Water: Living Machine 60

18. Black Water: Summary 63

$\begin{array}{ll}\text { 19. } & \text { Excel Comparisons }\end{array}$ 


\section{Introduction:}

This thesis will undertake the task of examining and redesigning the modern water system of an American home in a maintainable fashion, within the current infrastructure. The system will reduce water consumption to a level that will be sustainable while informing occupants discretely of their water usage and allowing them to make informed, sustainable decisions. The water system redesign will take into consideration aspects of the building occupants such as their desired standards of living, expectations and financial concerns. It will explore the difference between types of water contamination and basic, on-site treatment options. The objective is to reach a $90 \%$ reduction goal from 100 to 10 gallons, employing smart and tolerable lifestyle changes and currently available technologies.

Worldwide, water is a greater concern than any other natural resource. Eighty percent of illnesses in developing countries are water related (Kibert 2007, 217). Water pollution is a contributing factor in water scarcity; when water is scarce people may become desperate, drinking potentially contaminated sources. Only .3\% of fresh water is drinkable and accessible without sophisticated, expensive technology (Kibert 2007, 217). The health and lives of the people in developing countries are threatened by a lack of abundant water, while in developed countries lack of water threatens the quality of life. Water scarcity in large cities such as Los Angeles leads to drought issues and threatens a high standard of living. In cities, Americans are consuming on average 100 gallons of drinkable water a day, when only 2 gallons are required for living, and only 10 gallons to support a similar way of life. This is an unsustainable practice that cannot continue indefinitely with our current standard of living. 
The American way of life is being challenged by strict water restrictions and shortages (Hinrichsen and Robey, 2000). The water infrastructure right now cannot support the current demand, and changes must be implemented from the ground up. Companies have taken cues from consumers and have begun offering certain appliances and fixtures to the water conscious. Laws have also been enacted relating to water fixtures and appliances, such as low flow toilets and maximum flush restrictions. This however is only the first move to start the reimagination of the system, and it has to begin with small changes. Currently available water appliance fixtures will soon become the backbone of a system redevelopment that takes in the next scale of comprehensive redesign: the entire residential water system.

\section{Objectives:}

This thesis is the investigation of different water conservation strategies and systems in the residential home, taking averages from the Irvine area census. The thesis will explore the financial implications between the different systems as a cross comparison and as a return on investment. It will also account for ecological and social implications, for the occupants and their standard of living and lifestyle changes. The thesis will explore the ability to conserve water in new residential construction and will provide a sustainable and conscientious schematic water design for the particular area of concern.

This thesis exploration will act as a preliminary case study for the water system in an average California residential home (Irvine, CA census will be used for average values). It will address the entire lifecycle of water after it arrives on site, to the use of 
the water and eventual expenditure. Based on the body of knowledge in the field and the research findings, a comprehensive design solution will be proposed. The design will also evaluate the alternatives of different systems, in terms of: catchment, treatment, filtering, reuse, and returning the used water into nature. It is expected that the proposed system will inform the occupants of their water usage, and simultaneously control and reduce water usage levels. This will be in an overall effort to educate potential occupants and developers while compiling knowledge of currently available systems.

\section{Research Methodology:}

Since the thesis research is focused on improving upon existing water systems, the research will begin with an exploration of existing water systems with the use of current technology. Based on a literature search of books, research papers, and professional articles, this proposal will result in a summary of existing water systems in residential buildings. From that starting point, the research will explore emerging system alternatives. For this step, research will be supplemented by interviews of applicable experts. Company catalogues of water saving fixtures and emerging designs will be taken into account as well. These methodologies will form the backbone for the initial and final analysis stages of the project.

Involving subject matter experts in the fields of water contamination and water conservation strategies will balance out the theoretical research approach. During this stage case studies will be analyzed to direct the combinations and implementations of 
systems in real world environments. The case studies will also provide insight into potential problems from past experience, as basis point for innovation. The combination of these research methodologies will provide a well rounded backbone for the development of a balanced design solution that is project dependent.

\section{Sustainability and the Concerns of Water}

In the last few years sustainability has become a major topic of discussion in developed societies. With the growing awareness of our detrimental impact on water quality and availability, concerns have been raised in regards to what our future will entail. Popular press exemplifies this, as news sources have dedicated entire sections and headlines to environment and sustainability to educate the public. Sustainably is capturing the economic market as well; roughly $\$ 27.6$ billion has been spent in corporate sustainability development with a projection of $\$ 60$ billion by 2014 (Clancy 2010). Corporations are shifting to practices that will allow them to continue business into the future, both for marketing reasons but also to allow continued development with decreasing natural resources. Expert analysts expect green building market share to at least double over the next five years, reaching $20 \%$ of the market with $\$ 70$ billion being spent (Russo et al. 2008, 2). The focus of modern society is shifting to long-term ecological understanding to enable us to continue to thrive and develop.

Worldwide, water is a greater concern than any other natural resource. Eighty percent of illnesses in developing countries are water related (Kibert 2007, 217). Water scarcity and contamination are intimately related though; when water is scarce people are forced to live on bare minimums and drink potentially contaminated sources in 
desperation. This is compounded by the fact that only .3\% of fresh water is drinkable and accessible without sophisticated, expensive technology (Kibert 2007, 217). The lives of the people in developing countries are threatened by lack of abundant water, while in developed countries lack of water threatens our way of life. Water scarcity in large cities such as Los Angeles leads to droughts issues from maintaining our high standard of living which generally involves excessive water usage and waste. In cities, we are consuming on average 100 gallons of drinkable water when only 2 gallons are required for living, and 10 gallons for a comparable way of life. Water consumption levels are at an incredible excess and the population will have to find smarter methods of use, or change their standard of living.

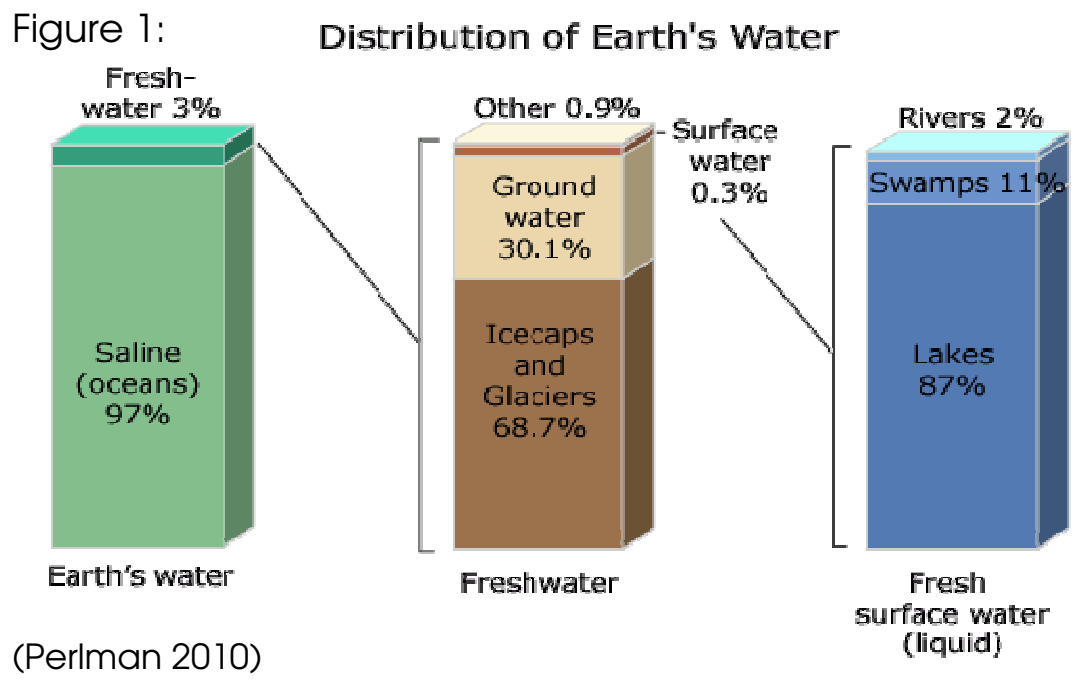

Among the resource and energy concerns, water falls below the radar in developed societies because it wasn't an immediate concern until recently. Droughts are now appearing nationwide in the United States and are even more intense in other areas like Asia. The global population is currently depleting water stores at an unsustainable rate, that natural and in place systems cannot replenish. In Arizona alone 
they are drawing two times the maximum water replenish rate every year (Kibert 2007, 217). Governments are beginning to step in and use taxes to incentivize conservation. Los Angeles has enforced tight enough regulations to warrant an $18.4 \%$ drop in water use (Gottlieb and Cruz 2010). If this depletion trend continues, cities will be forced to adopt alternative, less appropriate methods to replenish water, such as large volume desalination. If the populace cannot overcome high demands for water use, we will be forced into an inefficient technological development.

The cost of water is also an important factor when considering the scarcity and importance of potable water. Currently the cost of water is not truly reflected by the price the end user pays for it. Infrastructures have been generally in place for many years and supported by bonds and taxes. In New York, about 9\% of taxes go directly to the water infrastructure development and maintenance (Emily and Mandy 2011). In other cities the direct impact of taxes is much more difficult to put a dollar amount to, but in almost all cases taxes play a crucial role. The EPA estimates that tax-financing covers around $18 \%$ through grants and loans and that state and local governments invest $\$ 28.5$ billion in wastewater treatment and infrastructure. That is a cost consumers never directly see impacting their own personal water costs.

\section{The Age of Droughts}

Worldwide droughts have been more prominent and have greatly impacted the population's way of life. Australia is a prime example of this ecological trend; its longterm droughts have shaped building code changes and lifestyles. The country has endured over 3 years of drought and has depleted its water reserves to less than $30 \%$ as 
of 2010 (Carpenter 2010). This has encouraged over half of the residences in Australia to use grey water systems, especially with current trends according to the Australian Bureau of Statistics. Droughts have even caused issues when the rain resumes, as the barren soil is not as equipped to receive large volumes of water in a short time span. With this raging drought causing a plethora of issues, the way of life and construction practices in Australia have evolved into a more sustainable manner.

Droughts have become a common occurrence in the United States, yet still don't weight heavy on our lifestyle decisions. Last year alone, over $75 \%$ of the country experienced abnormally dry periods of weather, but some sections were hit harder than others. There is an emerging pattern indicating the South and Midwest sections of

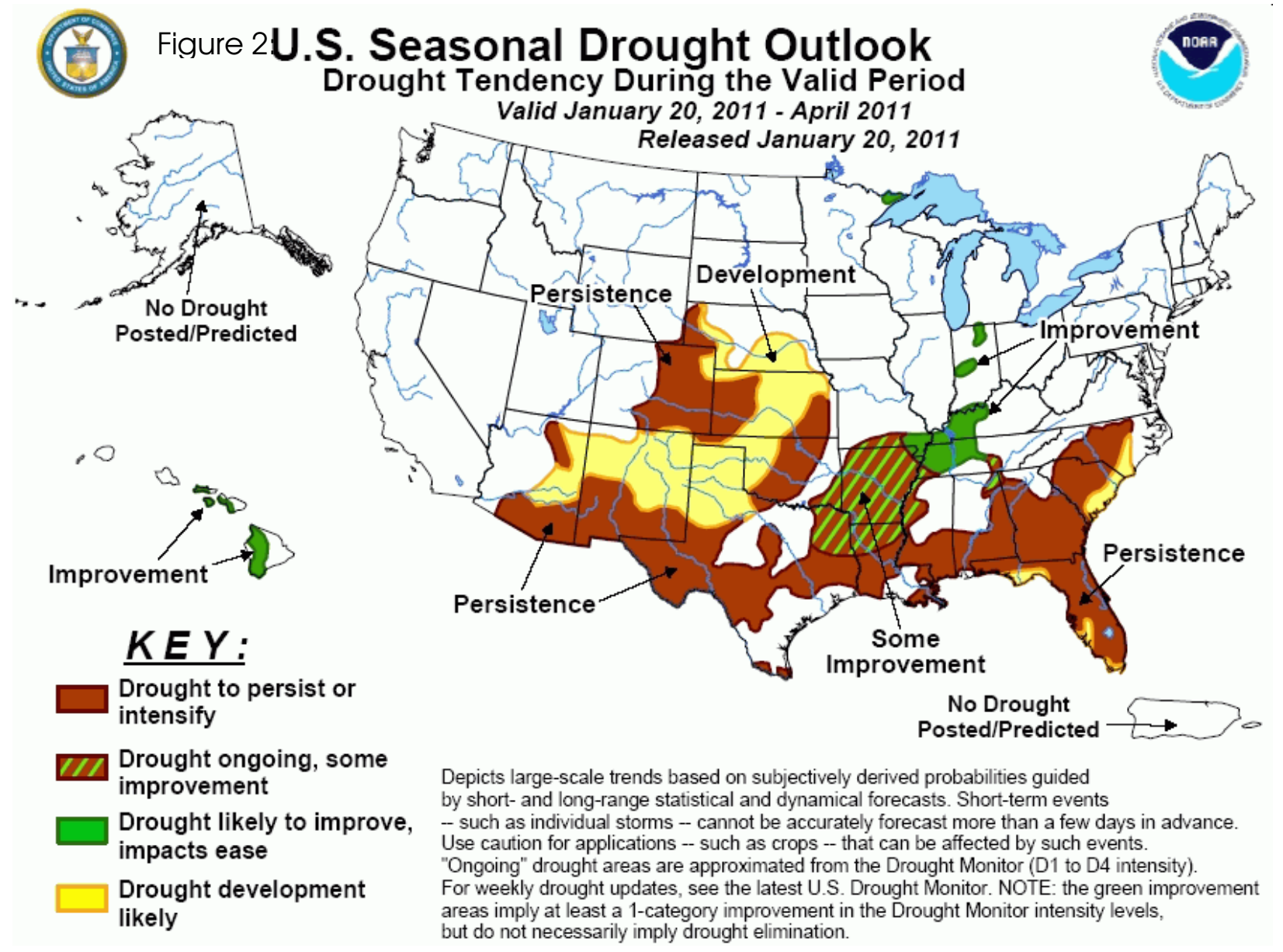


the nation are being hit hardest by these droughts. The Wall Street Journal published concerns over the "... worst prolonged shortage of rain expected in a 25 -year period" (McWhirter 2010). This is affecting crop's growth and the standard of living for many American families in these areas. Future predictions are not looking favorable either, with high chances of continuing trends of water shortage.

Much movement has been made out of the spotlight to develop water conservation sustainably. Organizations such as the Green Building Counsel have developed tools oriented to evaluate sustainable design. These tools such as LEED primarily have a water component, focusing on minimizing potable water use and taking advantage of the site to gather and process water. In the case of LEED, there are many shortcomings in the rating system. First off the points allotted to water conservation are a very low percentage. In conjunction with that there are few water considerations given to location. For example, with the LEED system, the points awarded to a water-saving system in New Orleans and one in Phoenix are equal, whereas the real world impact is much different. These current systems are a good start, but are in need of further development.

There are other organizations such as Earth Craft House that have also been developing tools for the average homeowner to make smart, sustainable decisions (EarthCraft, 2011). They have guides and white papers on their site addressing topics such as how to integrate a water catchment system and how to greatly reduce water consumption in residential homes. This system is more environmentally conscientious but currently lacks the popularity of systems such as LEED. These systems are less about 
rewards and merit and instead, merely educate. These two systems are vastly different but each system has major strengths and weaknesses.

Why hasn'† water conservation been a bigger sustainable issue? There are many factors that have led to the water issue being overlooked, primarily the low cost of water. With US water prices averaging around $\$ 6.29$ per thousand gallons in 2006 , there was little fiscal incentive to reduce water consumption (BNET 2006). This price factors out to a little over half a cent per gallon in the United States, making water conservation a much less short-term, economically driven decision. This means that people are not being persuaded by the immediate cost alone to conserve or reconsider wasteful practices. For this reason we must consider the short term fiscal concerns as just one of many influencing factors in making sustainable water decisions.

User level water prices, although currently low, do not accurately depict the high cost of treating water and bringing potable water to the tap. Government plays a large role in keeping water price levels reasonable for the average consumer. About 9\% of our tax money contributes to maintaining the water infrastructure (Emily and Mandy, 2011). This is disincentivizing water conservation in consumers and leading to a public misunderstanding of the real value of potable water.

These influences on decision only account for part of the overall problems regarding water. One of the biggest factors is the lack of knowledge of users. Even with droughts in major cities and threats of depreciating potable water sources, the population continues to ignore the water crisis. According to market research, lack of education and lack of awareness are both in the top five

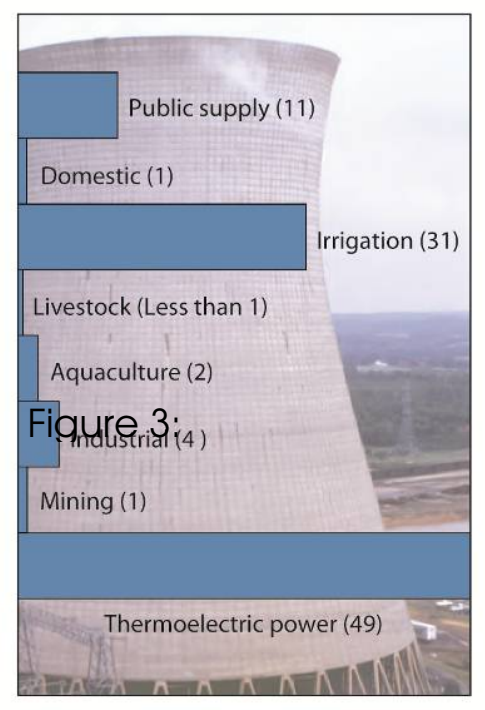


"...obstacles impacting the expansion of green building" (Russo et al. 2008, 26). This is readily apparent in the way we come about reducing water. Little is done to change habits and instead we change out fixtures and appliances in a "fix and forget" approach to sustainability. In Los Angeles, in the height of the water crisis around 2008, residents could still be seen watering their lawns and washing their cars in the driveway, needlessly wasting potable water (Schoch, 2008). On an individual basis, there is little understanding about the levels of water consumption in daily activities. The global naiveté regarding water leads to unsustainable practices and the only appropriate reaction is education.

\section{Project overview}

This project will be aimed at tackling the water concerns in a residential home. The residential building type was chosen for many reasons in this thesis proposal. Although a small overall part of the water network, residential has the biggest direct impact on occupants in their daily lives. This enables the project to inform a vast number of occupants about the water implications of everyday routines. This directly addresses one of the major problems of water conservation, knowledge. Residential design also allows for immediate or near immediate enaction of conservation techniques and strategies. This means that in contrast to overarching infrastructure changes, we can begin seeing conservation results in the very near future. It also has implications economically. With greater user demand for water conservation systems, prices will be driven down and will contribute to a positive feedback loop. This means that addressing residential specifically, we will directly and indirectly address the main 
issues with current water conservation: economic feasibility, social awareness and physical available systems.

By selecting the residential sector of the market for our study, we are also allowed opportunities to explore varying intensities of conservation strategies. This thesis proposal will act as a cross reference between the major options in residential water conservation in 4 different degrees, comparing them on a multitude of criteria:

1. Existing home fixture replacement

2. "Down-cycling" water with a grey water reuse system

3. Grey water in combination with rainwater catchment and treatment

4. Off the grid, on site catchment, treatment and reuse

From this thesis, a comprehensive guide will be developed. This will not be just an analysis of current strategies but a cross comparison of these different alternatives. This comparison will weigh heavily on the rewards and setbacks between the different systems. The comparison will be made upon many different criteria but not limited to: cost, buyback period, environmental impact, social implications, and future projections. Criteria for the comparison will be made based off of fiscal and social impacts, useful for both developers and occupants for planning and knowledge purposes. 
Residential Project Selection 


\section{California Residence}

California was selected for a wide variety of reasons for this thesis proposal. First off, I have lived in many parts of California for my entire life and through work have many years of experience with construction, building codes, and designs of California residences. Areas of California also show rapid growth as people flood metropolitan areas and the surrounding communities. This gives the project a unique opportunity to be realistically applied to a real life scenarios. California also has the highest demands on water in the country. This makes a water conservation project have an even bigger

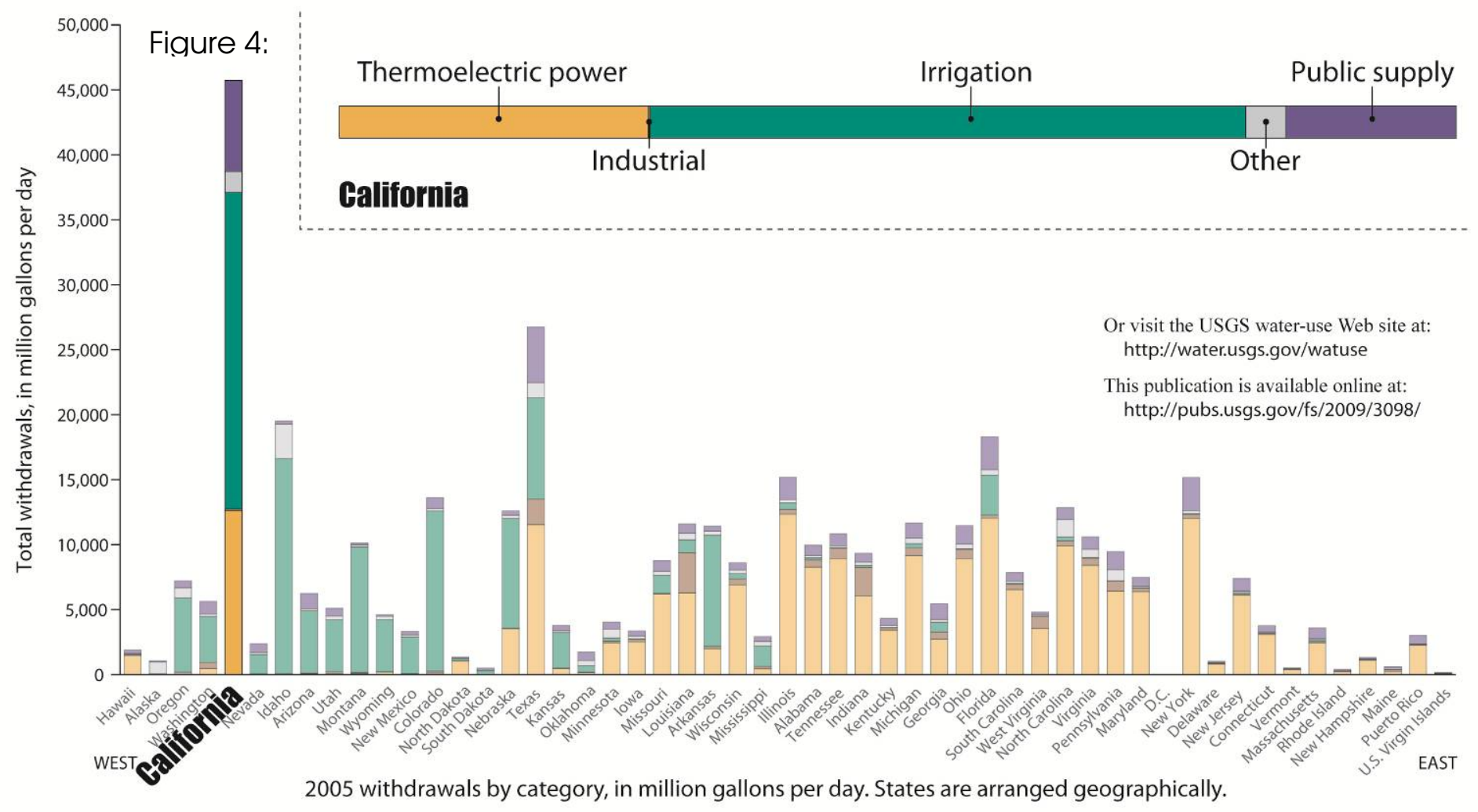

impact on communities and the overall water scheme.

To develop this project realistically, a specific area in California was required to be the focus. For this project to have the greatest impact on American residential design, it needs to be suitable for many developing areas and across many different 
categories. The largest conservation impact might come from a city that was rapidly growing in size and developing residentially. Also a city with limited avaliable local water would make a greater difference. From this perspective, Irvine, California was the best suited among the different selection criteria and relevence. Over a 6 year peiord, Irvine had one of the largest growth rates, around five times the average in California (US Census Bureau, 2011). Water conservation in these developing areas could impact a large number of occupants.

\section{Irvine Company}

Irvine was chosen for not only its growth rate but its structure. The city of Irvine has a unique relationship with The Irvine Company (http://www.irvinecompany.com/), a private real estate development entity. Irvine, the city, came into existence in 1971 as the Irvine Company developed and sold properties to the public. From these properties a city arose, built around developed "villages," as the company calls them, each with its own style. This node-centered conglomeration of villages makes up the body and the overall infrastructure of the city. The company has therefore been directly responsible for masterplanning of the city and the bulk of completed developmental projects in the area. This unique, privatized nature of the city has interesting side effects when talking about residential development.

The Irvine Company's relationship with the city has a unique way of sheltering it from economic volatility. In the economic slump, private companies with regular income and capital can still continue to develop and expand, while other systems are limited by loans and investors. This has a direct impact on the project as it allows for 
large "village" style developments to all take advantage of residential water conservation, implementing more complex systems into the initial design. This compounds the residential water savings and will directly affect the feasibility of the system implementation. This also allows for The Irvine Company to push water conservation agendas in major developments, when users might initially resist. Both features couple together to accentuate the effectiveness and acceptability of sustainable water management.

Aside from economic viability of this area, The Irvine Company's relationship provides other advantages when it comes to cutting edge development. Because of the Irvine Company's direct impact on the city, they are allowed to be more innovative when it comes to new systems and strategies. They have the financial backing to implement large scale case studies and to pass them through the local government more easily than other entities. They have developed a mutually beneficial relationship with the city, allowing the company to work cooperatively with the city.

The City of Irvine

The city of Irvine has desirable city statistics in addition to having a unique structure. Climatically, Irvine has relatively low precipitation levels, barely reaching and average of 3 inches a month in the wet seasons compared to California's January average of 4 inches (WRCC, 2011). In this area, there is also a big swing between winter and summer months in regards to rain. The large precipitation swing means that there is a rainy period of winter and a very dry summer. This makes it a unique challenge for more extreme water strategies such as rainwater catchment. Furthermore, the 
demographics of the area are ideal for this type of thesis project. There is a slightly above average monthly income, as well as corresponding housing prices. There is also a high density, meaning there will be tighter constraints on land size more suitable for metropolitan or urban conservation methods. These influencing factors mean many of the conservation and usage strategies can be extrapolated to other areas of the county.

Table 1: 2005 U.S. Census Bureau for Irvine and

\begin{tabular}{lll}
\hline Information & Irvine & California \\
\hline Population 2006 Estimate & 193,956 & $36,457,549$ \\
Population, Percent Change April 1, 2000 to July 1, 2006 & $34.6 \%$ & $7.6 \%$ \\
Population, Percent Change 2000 to 2010 & $49.8 \%$ & \\
Homeownership rate, 2000 & $60.0 \%$ & $56.9 \%$ \\
Median value of owner-Occupied housing units, 2000 & $\$ 316,800$ & $\$ 211,500$ \\
Households, 2000 & 51,119 & $11,502,870$ \\
Persons per household, 2000 & 2.66 & 2.87 \\
Median household income, 1999 & $\$ 72,057$ & $\$ 47,493$ \\
Persons per square mile, 2000 & $3,098.1$ & 217.2 \\
\hline & & U.S. Census Bureau
\end{tabular}

Figure 5: 
Average Temperatures

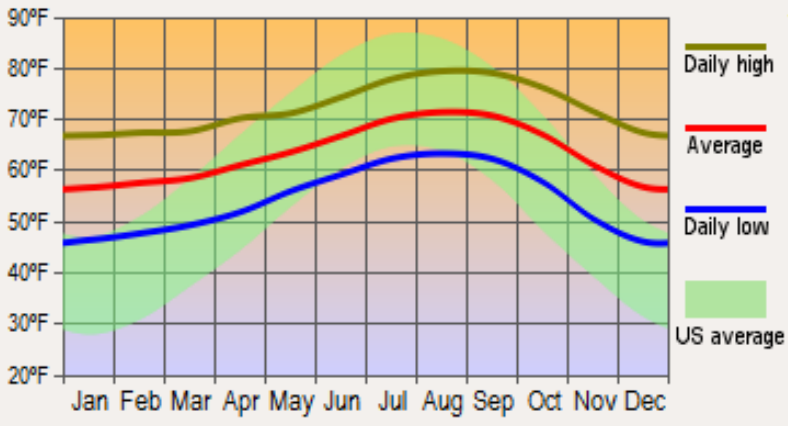

Precipitation

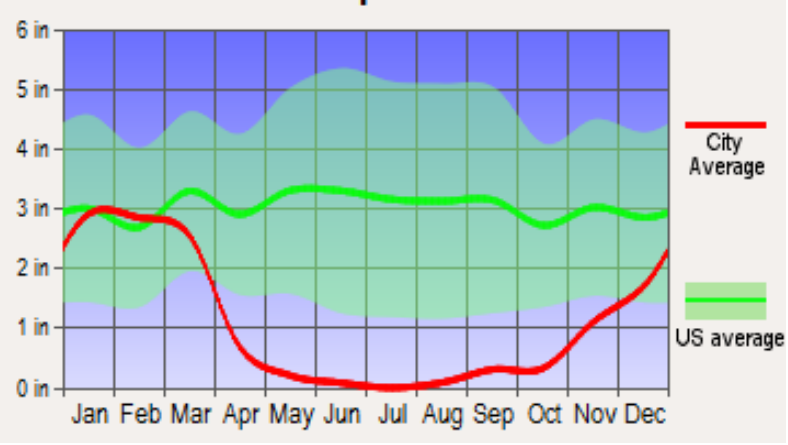

Humidity

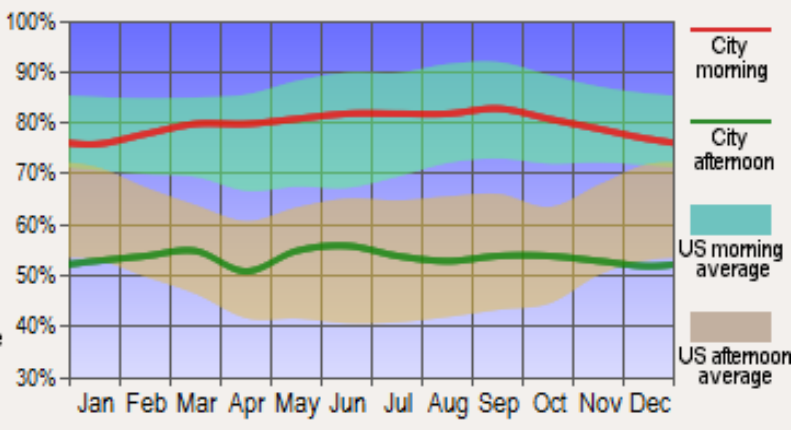

The source of water in Irvine is unique to the area and is an emerging situation for newer cities. Up until recently, Irvine imported about a third of their water from Northern California and the Colorado River (Water Supply, 2011). Waste water in Irvine is treated and pumped into the San Diego Creek and eventually into the ocean (Water Supply, 2011). The Irving Company is only developing water catchment in a commercial venue to be able to reuse as landscaping grey water. Currently their water input breakdown is as follows: 


\section{Figure 6:IRWD's Water Supply Portfolio}

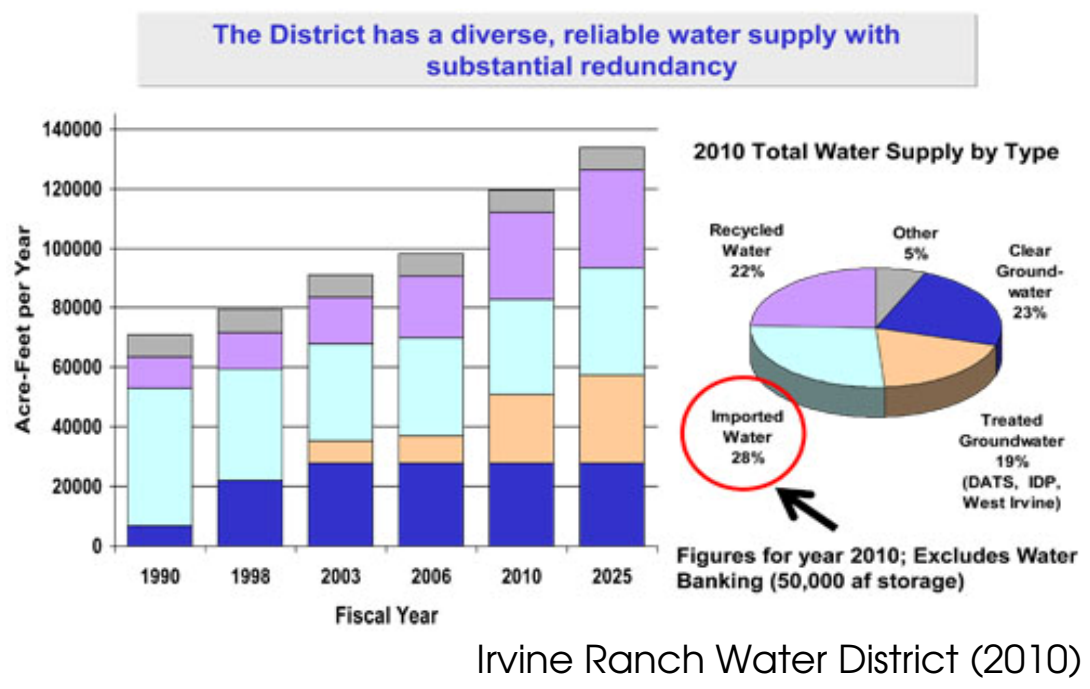

The Villages of Irvine

Irvine developments range in styles and form, but with a general theme throughout. Homes tend to have a modest exterior with little extra decoration and minimal landscaping. This is very beneficial for water conservation, having much less landscaping to support. They buildings have a large footprint on the site and push upon its borders. With landscaping usually consuming over half the potable water, a drastic decrease in overall landscaping area gives an immediate ability to conserve water.

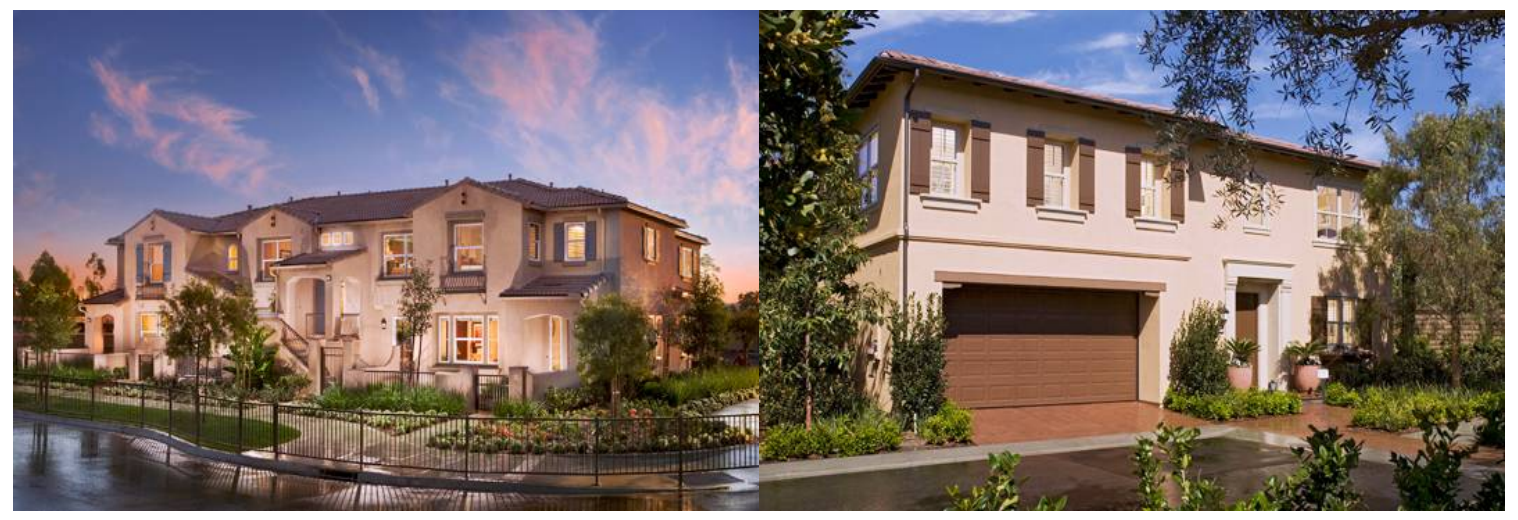



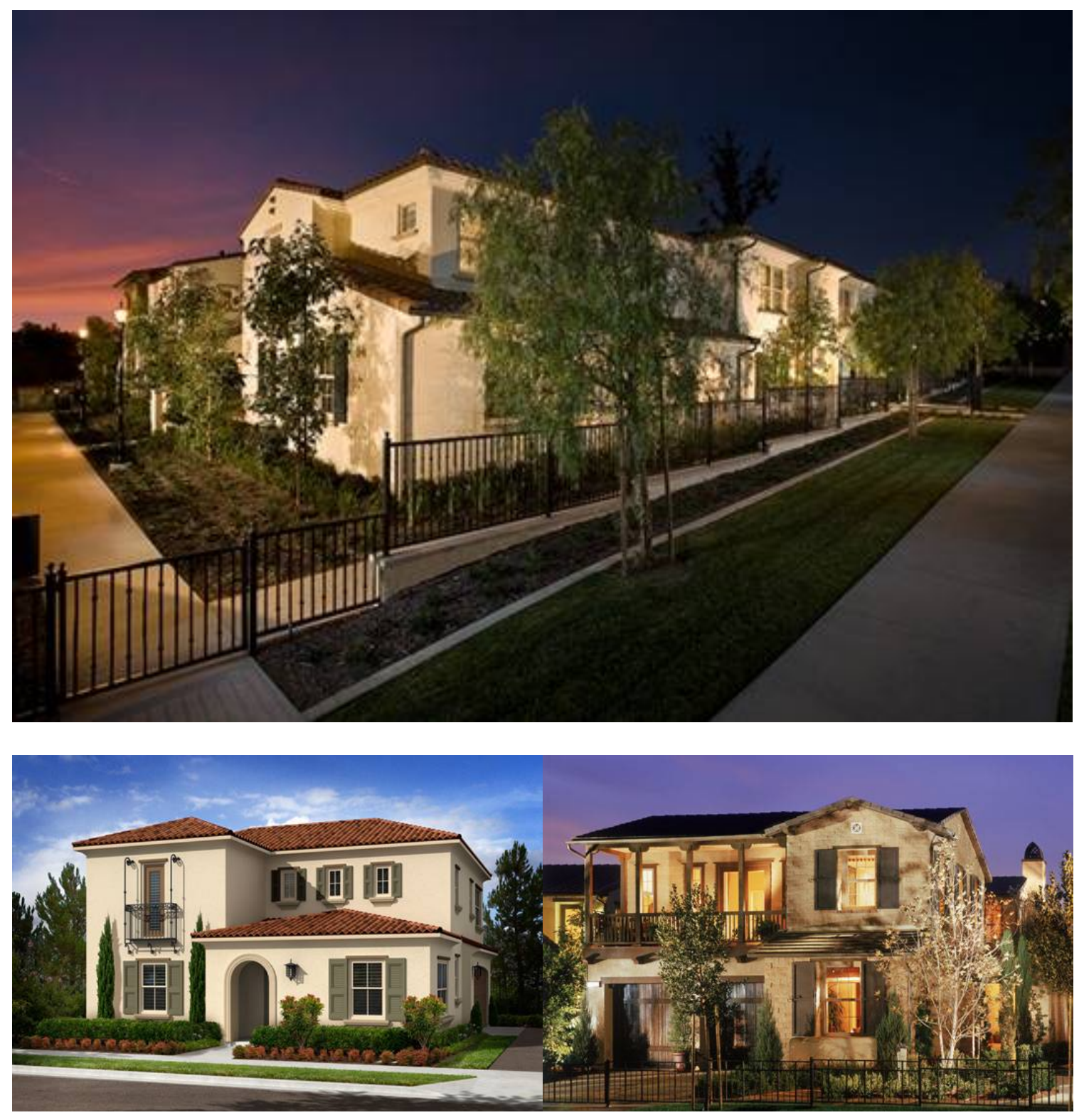

\section{Irvine's Water Financial Structure}

In developing a responsible water system in this area it is first good to understand how water is delivered in the existing communities. One of the most effective strategies in water conservation is "tiered water payments." This method of pricing water works much like tiered tax brackets work in economic systems. For this system, 
the price of water is in direct correlation with not only how much is used but the necessity of that water. Baseline water costs are one of the lowest in the nation, but they punish excessive use by steep price increases. For a given occupancy, the Company decides baseline values and informs occupants. Based off of this number, the company can monitor water usage and charge accordingly, resulting in an incentive to conserve. This directly impacts the users, while teaching them about water conservation and rewarding better water practices. Interestingly, this goes not only for occupants but for the entire construction cycle. For example, if a construction company is mixing concrete on site, they would have to apply for higher water limits or pay a premium for overages. This tiered system punishes wastefulness, raises awareness at the user level, and adds inherent value to potable water.

\section{Figure 7:New Home Water Use - 174,000 Gallons/year}

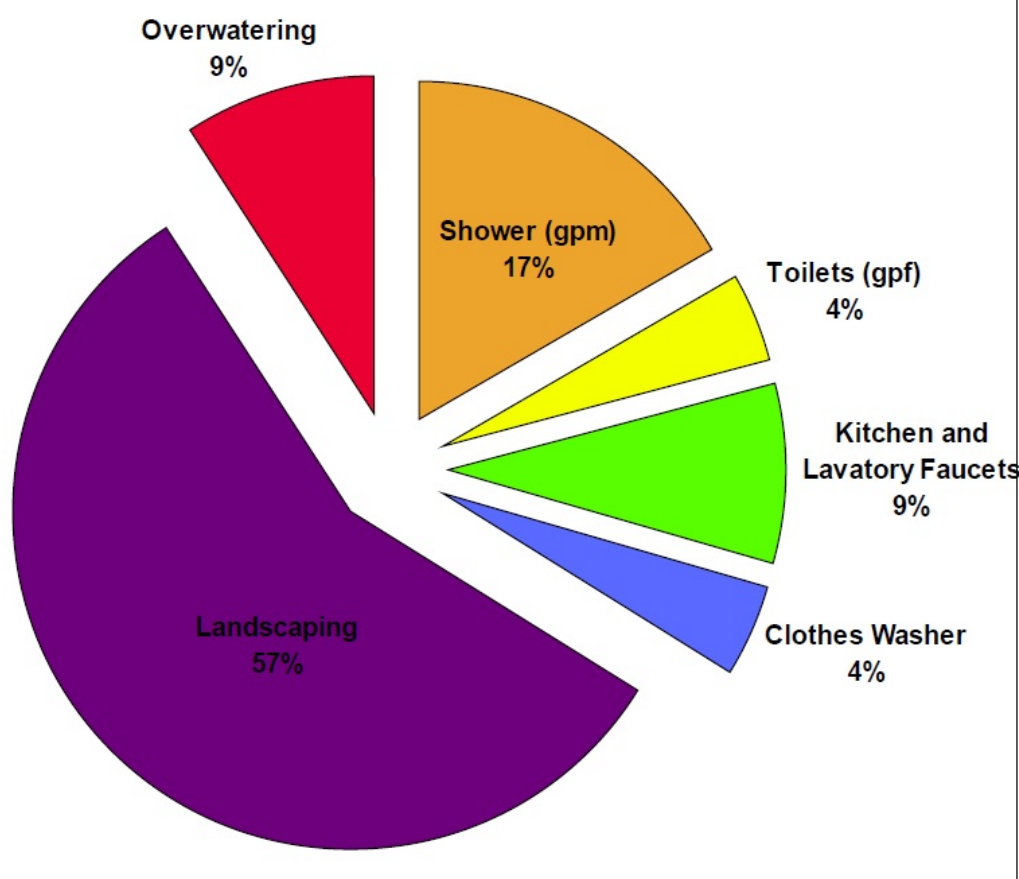


Table 2: Irvine Water Cost Structure

\begin{tabular}{|c|c|c|c|}
\hline & & $\begin{array}{c}\text { Percentage above Baseline } \\
\text { Usage }\end{array}$ & $\begin{array}{l}\text { Cost per ccf ( } 748 \\
\text { gal) }\end{array}$ \\
\hline \multirow{6}{*}{ 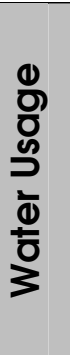 } & Base Potable & Under $0 \%$ & $\$ 0.91$ \\
\hline & $\begin{array}{l}\text { Base } \\
\text { Reclaimed }\end{array}$ & Under 0\% & $\$ 0.82$ \\
\hline & Inefficient & $0 \%-10 \%$ & $\$ 1.15$ \\
\hline & Excessive & $10 \%-20 \%$ & $\$ 2.33$ \\
\hline & Wasteful & $20 \%-120 \%$ & $\$ 4.65$ \\
\hline & Over & Above $120 \%$ & $\$ 9.30$ \\
\hline
\end{tabular}

In conjunction with the tiered system of water pricing, the company strives in its infrastructure to keep good water practices. They implement many different water strategies, especially in commercial developments. They employ smart watering strategies to limit water lost to daily evaporation. When possible they deliver water directly to the roots of plants, and only when appropriately correlated with the weather. The city has infrastructure set to reuse water when available but currently do not capture or treat water on site. In the future, they expect turf to disappear, xeroscaping to become more popular, and drip flow to become more prevalent (C. Collins, phone interview, 2011). With these methods, the city of Irvine stands on the forefront of sustainable water conservation in the United States. 
$\underline{\text { Household specifications }}$

The household selected for this project is a prototypical one from the villages of Irvine. The house is designed to mimic the average statistics of the area (based off of the 2010 Census statistics). The house is $1,900 \mathrm{sq} f t$, has 3 bedrooms, 2 1/2 bathrooms, and is worth $\$ 680,000$ (Irvine Real Estate \& Irvine Homes For Sale, 201 1). This means a mortgage rate of around $\$ 3,400 /$ month (Mortgage Rates, 201 1). It is of new construction, primarily for the feasibility of implementing more physically demanding water conservation strategies that will be explored later in the thesis. The house is also on a lot appropriate for the median of the area, 4,500 sq ft (Irvine Real Estate Market

Figure 8:

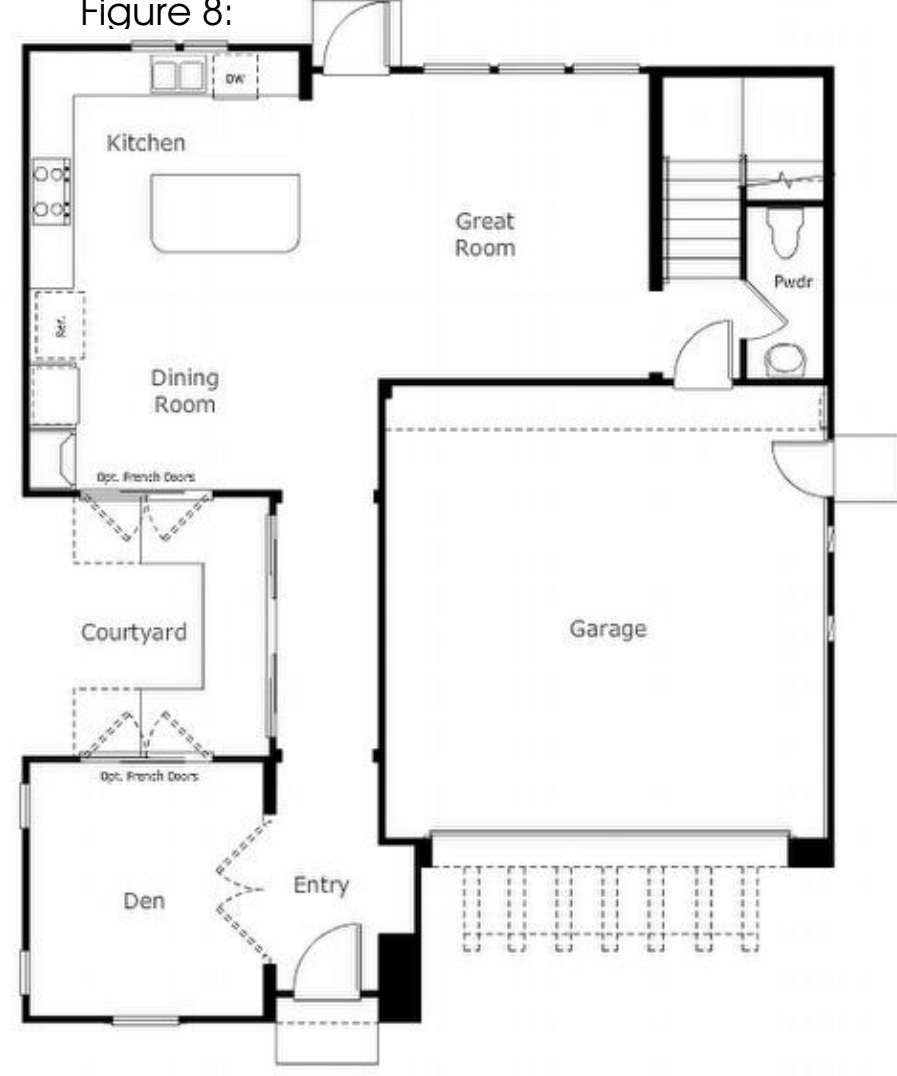

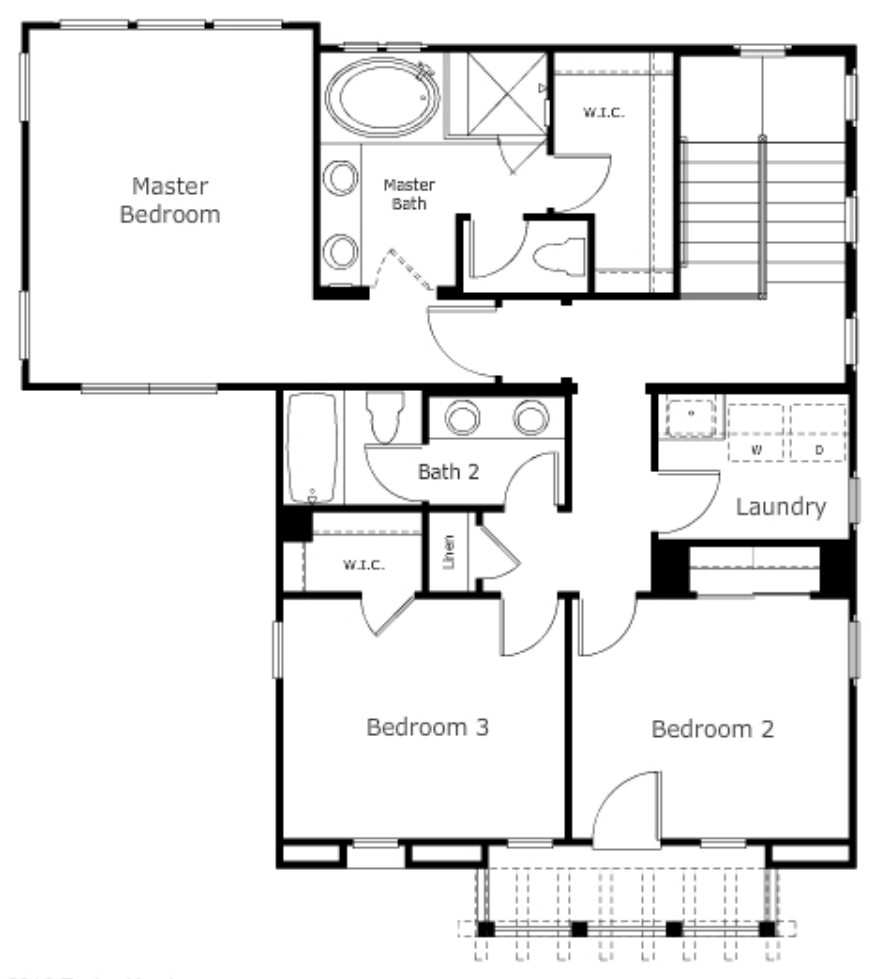

(c) 2010 Taylor Morrison 
Data, Trends \& Statistics, 2011). This plan is one currently being used in one of Irvine's many developments and fits the necessities of the project.

Floor plans (Taylor Morrison, 2010)

\section{$\underline{\text { Occupants }}$}

In order to effectively design a residential water solution we must not only select an appropriate household but understand the occupants. For the city of Irvine, the average household occupancy is 2.61, and average family size is 3.17 (US Census Bureau, 2010). For our case study we will be selecting a typical family of two parents and one child. Both parents are working and their combined income is $\$ 115,000$ a year, the median income for the area (US Census Bureau, 2010). Their lifestyle mimics that of an average American family; they water their garden regularly and are not currently concerned with water conservation. They are compassionate about green living, but unaware of the implications of their water usage. 


\section{Analysis Rating Criteria}




\section{$\underline{\text { Introduction }}$}

In order to compare such vastly different systems such as are presented in this thesis paper, we must establish criteria to evaluate between them. There is no one unifying factor for evaluating between the different water conservation systems so we must establish terms that can be cross compared. Many assumptions will be made with the project, with the body of them being drawn from averages in the region as a baseline value.

\section{Monetary Concerns}

One of the most important aspects of sustainable water conservation is the ability for it to be financially feasible. Without a water system being economically viable, it is near impossible to implement in a real world scenario. There are a couple different factors we must take into account for monetary concerns, the most important of which is buy back period. This is a financial tool used to calculate savings vs. initial cost of an investment over a period of time. Buy back period is this duration when the savings pays off the initial investment and the costs break even. We will be assuming an expected lifespan for the house at 50 years, so anything beyond that value will be considered a loss.

Monetary Model Assumptions:

1. $4 \%$ overall return on investment for the family

2. Water prices are on an exponential climb (extrapolated from Table 3: Predicted Water Prices

'03-'08 data) 


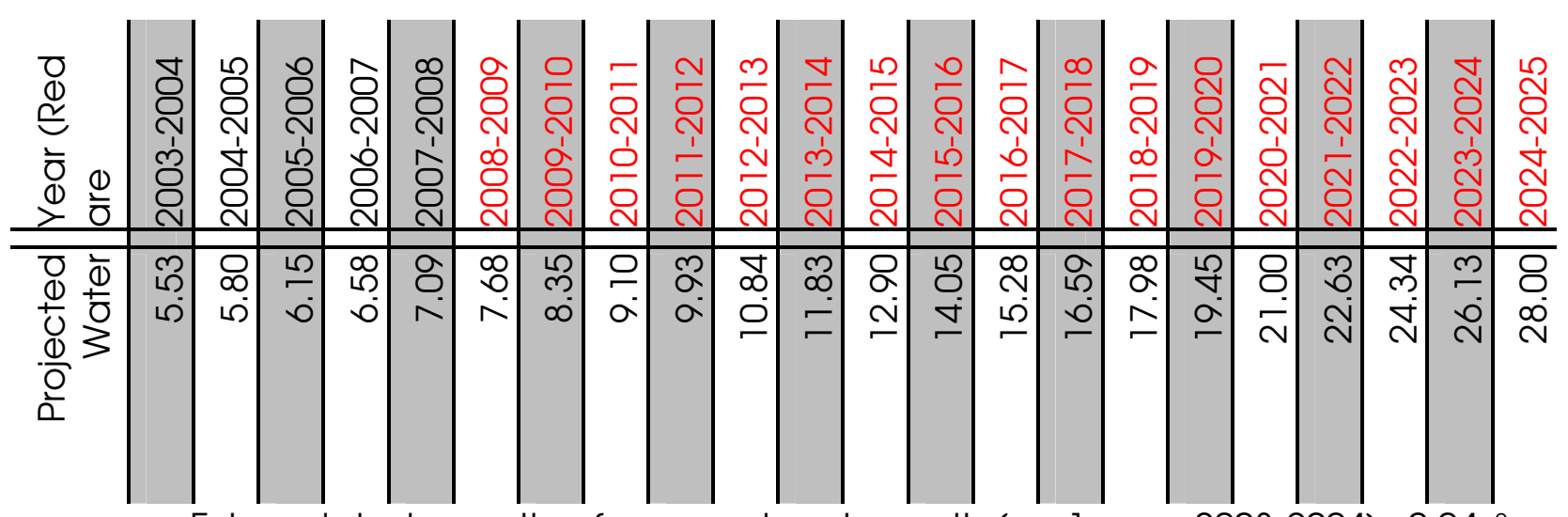

Extrapolated equation for annual cost growth ( $x=1$, year 2003-2004): $0.04 x^{2}+$

$0.15 x+5.34$

3. Inflation is at a constant $2.5 \%$ based on 2000-2010 (Current Inflation, 2011)

4. Family income remains stable

Tax implications have been removed in these monetary model assumptions for a few key reasons. In many cities there are huge savings to be had either through incentives or through write offs. Unfortunately these systems are usually short lived, and generally are not focused on water conservation but instead solar or energy. The value of these tax incentives is also rarely constant between cities or states. Finally, the government incentive drives industry, but does not actually affect price on a large population base as taxes are just a reallocation of wealth. Because of these factors, government incentives will be left out of our calculations but are something to be noted when applying core concepts to real world applications.

\section{Ecological Impact}

Ecologically, occasionally people must place a monetary value on sustainability to justify investment. In order to account for this is a cross-comparison basis of water 
conserving alternatives we must establish a value for sustainability. For this project we will assume that the occupants are willing to sacrifice $10 \%$ of their income to invest in cutting edge sustainability, although there is much opportunity to recapture that investment. Our residents have decided to make these funds available to become forerunners for water conservation sustainability.

\section{$\underline{\text { Social Implications }}$}

Lifestyle and attitude changes are the most intangible and difficult to rate. New systems fail or succeed depending on how easily they are adopted into daily lives. The biggest component to this application of lifestyle is people's natural resistance to change and inconvenience. New systems often fail to be adopted into the mainstream due to the sacrifices users must make. This will become a major factor in the decision process, yet since little research has been done on psychological obstacles these systems might have to overcome (mostly pertaining to inconvenience, much speculation will have to be done in this category. We therefore must break down a rating system that is correlated to our lifestyle and standard of living:

1. None - No change to lifestyle and the system would be adopted by almost anyone.

2. Subconscious -Education has subconsciously affected their standard of living but there is little inconvenience. Examples of this might be learned behaviors like not letting the water run while brushing teeth or spending hours in the shower. 
3. Minor-Sacrifices might have been made but they mainly affect how things are done but are not terribly limiting. An example of this would be filling up a sink basin to wash dishes instead of letting the water run the whole time.

4. Medium - In this level sacrifices are more noticeable but the most sustainably conscientious households are willing to make the sacrifices. An example for this would be taking 10 minute showers or less. Here is where much of the population won't participate due to inconvenience.

5. Major - Here is where $90 \%$ of the population won't participate due to the changes required by the sustainable method. Composting toilets would be in this category for they require total change of diet to keep the system healthy and functioning. 


\section{Understanding Water}




\section{$\underline{\text { Introduction }}$}

To understand water and the options we have in residential construction, we must first understand what potential problems arise with water. Between pH balance and a multitude of regulated contaminants, water has a very narrow safe zone for human usage in the home. Potable water, water of high enough quality to drink, is held to the highest standard of control for human safety. Water at a lower tier in quality is referred to as grey water, used for non-potable means such as washing. Water used by occupants and that is unfit for reuse is referred to as black water, has to be treated before returning to the environment or reuse.

\section{Types of Contaminants}

Typically water is classified in four different subcategories, each causing different issues related to water contamination. In addition to that there are many other concerns regarding water treatment, including $\mathrm{pH}$ and salinization. These in conjunction with the main four contaminate categories require a delicate balance to be considered potable water that can be safely used in contemporary residential homes.

First in the categorized contaminants is what is referred to as large solids. These solid chunks of material are non-drinkable due to their mass but also run many other risks of plugging pipe works and infrastructure. The constitution of these large solids is less important than their size and structure in the water. Large solids are treated through many methods; one of the primary means is through filtration. Screens and other similar filter mediums separate the particles from the water by allowing the water to move on 
in the system, holding back solids. In more natural processes (such as in nature) this is done by dirt and sometimes by solid decomposing bacteria. In artificial living machines, the difference in densities of the solids and water make separation effective by lettings the solids settle to the bottom or float to the top.

The second classification of contaminants is organic components. These are small (relative to the first solid category) particles formed of biomass. These cannot be treated in the same method as the larger solids, as often they are too small to be separated from water by size (filtration). These particles commonly include carbon and nitrogen which are common to water naturally, but can be detrimental in the wrong dosage (an overabundance of nitrogen not only can hurt humans directly and become toxic but can affect body functions in areas like the kidneys). An improper balance of nitrogen can lead to algae growth; this causes solid build up in the water, the removal of oxygen from the water by the plants and a lack of deep sunlight stimulating bacteria growth. Natural and man-made systems of treatment work using microorganisms to digest/process excess of these organic materials. Organic components are not harmful on their own, but when out of balance in a water system it can cause big problems (Nitrogen..., 2011).

Counter to organic components, there are also inorganic, metals and other minerals. These are dangerous in the water supply for many are toxic (such as heavy metals). There is a great range of possible symptoms from these chemicals: copper can create liver/kidney failure, fluoride can cause bone disease, lead poisoning can lead to kidney or blood pressure issues etc. (EPA, 2011). These heavy metal problems are solved naturally by dispersion in the environment. In wastewater treatment plants, 
these minerals must be individually monitored and treated with the addition of more chemicals. This leads to a greater strain on the environment through the creation and disposal of these counter chemicals.

Living organisms can also contaminate water sources and these are referred to as microbial contaminants. This is one of the largest sources of concern for water quality because it has the highest risk of injury. In this category, we have many of the water borne illnesses that are prominent in third world and developing countries. In wastewater treatment there are many issues with microbial contaminants which must be managed. In many cases this means ultra violet treatment to break down cell structure. Chlorine treatment also does the same thing and in living machines, the final filtration does the work removing even the smallest of microbes.

Table 4: Appliance Level Contaminants and Needs

\begin{tabular}{|c|c|c|c|}
\hline Area & Appliance & Contaminants & Need \\
\hline \multirow{6}{*}{ 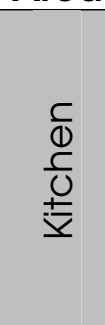 } & Dishwasher & Food Particles & Non-potable Sterilized \\
\hline & & Cleaners (Dish Soap) & \\
\hline & Sink & Food Particles & Potable \\
\hline & & Cleaners (Intense) & \\
\hline & & Grease & \\
\hline & & Oil & \\
\hline \multirow{7}{*}{ 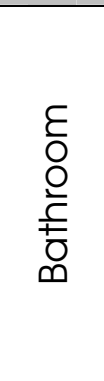 } & Shower/Tub & Hair/Skin & Non-potable Sterilized \\
\hline & & Dirt (Solids) & \\
\hline & & Cleaners (Soap) & \\
\hline & Sink & Dirt (Solids) & Non-potable Sterilized \\
\hline & & Cleaners (Soap) & \\
\hline & Toilet & Black Water & Grey \\
\hline & & Solid Waste & \\
\hline \multirow{3}{*}{$\begin{array}{l}\frac{\overline{0}}{\overline{\frac{D}{D}}} \\
\frac{\bar{x}}{\mathrm{u}}\end{array}$} & Landscaping & Pesticides (Potential) & Grey/Black \\
\hline & & Fertilizer (Potential) & \\
\hline & & Runoff (Solids) & \\
\hline \multirow{3}{*}{$\frac{\bar{\Phi}}{\stackrel{ \pm}{ \pm}}$} & Clothes Washer & Hair/Skin & Non-potable Sterilized \\
\hline & & Dirt (Solids) & \\
\hline & & $\begin{array}{l}\text { Cleaners (Medium } \\
\text { Intensity) }\end{array}$ & \\
\hline
\end{tabular}


Setup of the Infrastructure

Currently the infrastructure is not a closed loop and still requires an environmental step in the process. This is primarily due to the pushback consumers have about installing a water recycling center, also referred to as "toilet to tap".

1. Water is first collected in lakes and reservoirs

2. It is tested and treated in facilities

3. It then moves down aqueducts and pumping stations to residences.

4. There it is used and the sewage byproduct is created

5. This is pumped away and treated before being released into nature

$\underline{\text { Infrastructure Critique }}$

Currently there are significant issues with the infrastructure of water treatment and delivery. The current infrastructure is in a state of decline and threatening to break down. The American Society of Civil Engineers expressed their serious concerns over the declining water infrastructure in the United States by giving the overall system a Drating in 2005 (Dixon and Buhrman, 2005). This is also a result of the lack of suitable funding for investing and maintaining the infrastructure. The population is increasing exponentially, creating an unforeseen toll on the system. In addition, the plants were only designed to last 20-50 years as well, and current treatment is not sufficient; "By 2016 pollution levels could be similar to levels observed in the mid 1970's" (EPA, 2002). The current financial demands on the water infrastructure exceed the $\$ 34$ billion that is currently being provided by the government water and sewer infrastructures (Census 
Bureau, 2010). This is a testament to the degradation of the overall system as well as to the inability of the government in keeping the current water system afloat. 
Appliance Level Systems 
$\underline{\text { Introduction }}$

This section of the paper explores the most conservative water conservation system and the most widely visible, the appliance level. At this level of the water distribution system, almost no change is made to living conditions or way of life which is why this level is the most accepted. Also in most cases changes can be applied to new or old construction, providing a larger population base that is affected by these conservation strategies. These strategies are not necessarily "cutting edge" and have been around for years which might explain why they are widely understood and adopted in many cases.

In selecting appliance level water solutions, the McMaster-CARR product catalogue will be utilized for interior fixtures. This is a commonly used resource in the local industry for finding base level products and reasonable prices. It is targeted at Los Angeles, California which is very nearby the project site which will mean that these products and prices are applicable to this project.

\section{Faucets $-9 \%$ overall use, $40.5 \mathrm{gal} /$ day average}

These are one of the most common appliances in the household and can be a significant overall source of waste. Most residential faucets average around 1.5 gallons a minute, with older fixtures having as high as $2.5 \mathrm{gpm}$. Just washing hands in a sink can easily take 1 gallon, where dishwashing can take upwards of 5 gallons. A three person family can easily use 40 gallons a day through sinks. This means that there is a big savings to be had by lowering flow rate or limiting running water time. 
Water savings can be achieved in two different ways; upgrading fixtures to low flow and aerators. Upgrading fixtures can lower flow rates and aerators can reduce flow while keeping a similar feel. Fixtures on average range between $\$ 40$ and $\$ 130$ for standard appliances and in new construction there is almost no cost different between high and low flow rates. Even replacing existing fixtures at an assumed cost of $\$ 85$ dollars, the appliance pays for itself in little over a year and a half.

Table 5: Appliance Level:

Faucet\$5 gal $/$ day * 365 day $/ \mathrm{yr} * \$ 4 / 1000 \mathrm{gal}=\$ 51.10 / \mathrm{yr}$ savings

\begin{tabular}{llll}
\hline Initial Investment & i & Annual Savings & Buyback Period \\
\hline$\$ 85.00$ & $4 \% / \mathrm{yr}$ & $\$ 51.10 / \mathrm{yr}$ & $1.64 \mathrm{yr}$ \\
\hline
\end{tabular}

In our case, we would be using an aerator at an average cost of $\$ 2.00$ and a minimum reduction of $20 \mathrm{gal} / \mathrm{day}$, and the buyback period is only a month. This is a high return on investment and the ecological savings makes it a worthwhile investment.

$$
20 \mathrm{gal} / \mathrm{day} * 365 \mathrm{day} / \mathrm{yr} * \$ 4 / 1000 \mathrm{gal}=\$ 29.20 / \mathrm{yr} \text { savings }
$$

\begin{tabular}{llll}
\hline Initial Investment & i & Annual Savings & Buyback Period \\
\hline $\mathbf{\$ 2 . 0 0}$ & $4 \% / \mathrm{yr}$ & $\$ 29.20 / \mathrm{yr}$ & $0.07 \mathrm{yr}$ \\
\hline
\end{tabular}

In summation, these two tactics provide significant savings for little additional investment. Not only is there a cost incentive but the ecological savings is also high at around $4.5 \%$ water savings (assuming a $150 \mathrm{gal} /$ day/occupant typical use). There are also no major lifestyle changes that are necessary to earn these savings.

\section{Showers $-17 \%$ overall use, $76.5 \mathrm{gal} /$ day average}

Shower heads conserve water similarly to the methods used above in faucets. Initially they merely restrict water flow, and secondly some devices aerate allowing the same feeling to be achieved with less water. Standard water heads use about 2.5 
$\mathrm{gal} /$ minute, while those conserving use less than $2.0 \mathrm{gal} / \mathrm{min}$. For new construction like our project these new showerheads that are WaterSense certified, as part of an EPA partnership program, cost an average maximum of $\$ 15.00$ more.

$$
15.3 \mathrm{gal} / \mathrm{day}{ }^{*} 365 \mathrm{day} / \mathrm{yr}{ }^{*} \$ 4 / 1000 \mathrm{gal}=\$ 22.33 / \mathrm{yr} \text { savings }
$$

\begin{tabular}{llll}
\hline Initial Investment & $\mathbf{i}$ & Annual Savings & Buyback Period \\
\hline$\$ 15.00$ & $4 \% / \mathrm{yr}$ & $\$ 22.33 / \mathrm{yr}$ & $0.68 \mathrm{yr}$ \\
\hline
\end{tabular}

By this calculation, these fixtures provide the same comfort while paying off in less than a year. This would provide an overall savings of $3.4 \%$ or $15.3 \mathrm{gal} /$ day. This comes at no lifestyle change of the users and in new construction without any extra waste and only a small added cost.

\section{Toilets - $4 \%$ overall use, $18 \mathrm{gal} /$ day average}

In the household, another leading cause of wasted water is toilets. In new construction there are code restrictions on the maximum gallons per flush. The 1995 National Energy Policy Act limits flushes to 1.6 gallons of water or less, with the previous averages being about 3.5 gallons. Old toilet designs could use upwards of 18 gallons/day/person. New restrictions keep that down to 9.5 or so, with our case study home averaging 28.5 gallons/day. With leading edge toilet water conservation, average gallons can drop to 1.25 gallons/flush with average water usage being 7 gallons/person, 21 gallons/day.

In older home renovations, converting to a low flush toilet can drastically impact water use as it cuts use in half.

Table 7: Appliance Level: Toilets

$$
25.5 \mathrm{gal} / \mathrm{day}{ }^{*} 365 \mathrm{day} / \mathrm{yr}{ }^{*} \$ 4 / 1000 \mathrm{gal}=\$ 37.23 / \mathrm{yr} \text { savings }
$$

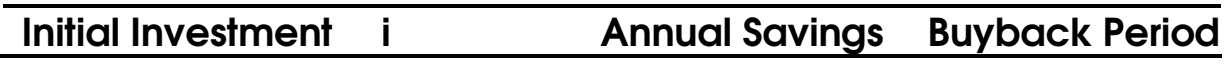




\begin{tabular}{llll}
\hline $\mathbf{5 0 . 0 0}$ & $4 \% / \mathrm{yr}$ & $\$ 37.23 / \mathrm{yr}$ & $1.33 \mathrm{yr}$ \\
\hline
\end{tabular}

In our case with new construction however, the water savings is only 7 gallons a day from all the users, but the difference between the fixtures' cost is only $\$ 25$ difference when buying new.

$7 \mathrm{gal} / \mathrm{day}{ }^{*} 365 \mathrm{day} / \mathrm{yr}{ }^{*} \$ 4 / 1000 \mathrm{gal}=\$ 10.22 / \mathrm{yr}$ savings

\begin{tabular}{llll}
\hline Initial Investment & i & Annual Savings & Buyback Period \\
\hline $\mathbf{2 5 . 0 0}$ & $4 \% / \mathrm{yr}$ & $\$ 10.22 / \mathrm{yr}$ & $2.38 \mathrm{yr}$ \\
\hline
\end{tabular}

Even though toilets are not the biggest water consumer there is much that can be done to reduce water consumption. On average buying a dual flush toilet can save $2.4 \%$ of the total water usage in the home. This area is also one of the few that code is beginning to drastically help (accounting for $2 \%$ total water savings). Fiscally and ecologically the low/dual flush toilets are a smart investment, but they do require a minor lifestyle change. Some education has to be instilled about the two different flushes, and for many consumers the availability of such products is still rather unknown.

Landscaping $-57 \%$ overall use, 256.5 gal/day average

This zone has the biggest potential for reducing water consumption in a household as it is responsible for over half the water use. In this strategy we will look at what can be done just by appropriate timing and replacement of plumbing parts in a water system. There are two main strategies when it comes to watering, above and below ground. Drip irrigation delivers water directly to the roots of plants, preventing a major loss of water through evaporation. This system is unfit for grey water use without treatment because of the reliance on the purity of water to "trickle" through the hose 
membrane. The other system is conventional sprayers which can be adapted for better water control and dispersion.

Assuming we are not changing the system, drip irrigation would be most beneficial with the typical potable water within the home. On average drip irrigation saves $50 \%$ water because nothing is lost to evaporation ( $90 \%$ efficiency instead of 50 70\%). Typical irrigation costs about $\$ .30 / \mathrm{ft}^{2}$ to $\$ .50 / \mathrm{ft}^{2}$ while drip irrigation averages from $\$ .40 / \mathrm{ft}^{2}$ to $\$ 1.00 / \mathrm{ft}^{2}$, our calculations will take the median costs of both systems. Table 8: Appliance Level:

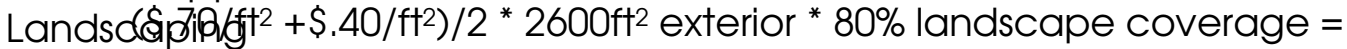

$\$ 1,144.00$

$$
128.25 \mathrm{gal} / \mathrm{day} * 365 \mathrm{day} / \mathrm{yr} * \$ 4 / 1000 \mathrm{gal}=\$ 187.25 / \mathrm{yr} \text { savings }
$$

\begin{tabular}{llll}
\hline Initial Investment & i & Annual Savings & Buyback Period \\
\hline $\mathbf{\$ 1 , 1 4 4 . 0 0}$ & $4 \% / \mathrm{yr}$ & $\$ 187.25 / \mathrm{yr}$ & $5.57 \mathrm{yr}$ \\
\hline
\end{tabular}

As the table above shows, as a new construction project the drip irrigation system does an excellent job at water savings with no social implications for the user. This would lower water use in the house by $28.5 \%$ for a short buyback period. This modification can be easily achieved in new construction, but is not as simple or inexpensive in existing structures.

\section{Summary}

The chart below shows how potable water enters the system and exits as black water into the sewer with no grey water introduced in the system. 


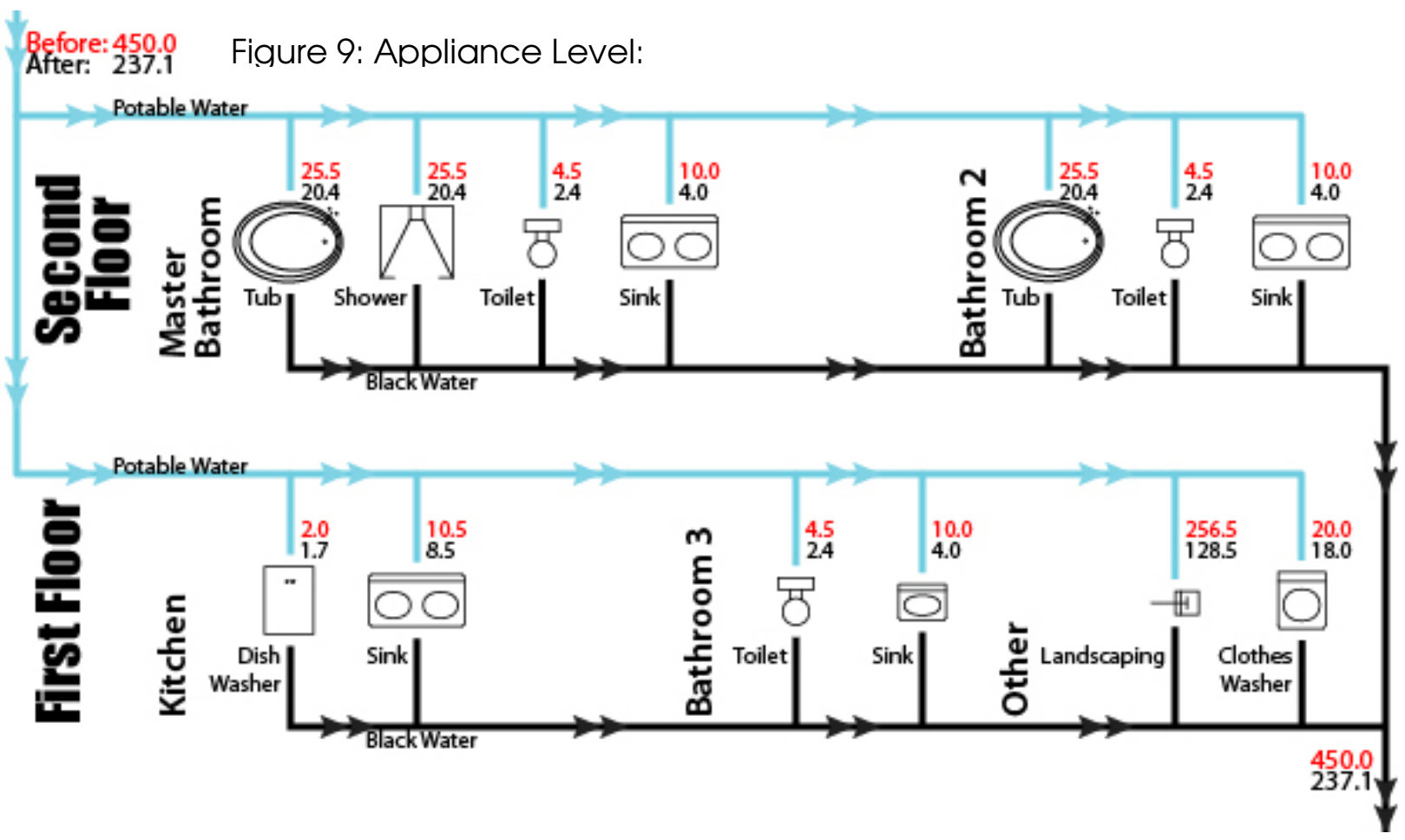

For financial investments we cannot just look at buy back periods but we need to also look at other investment tools such as rate of return and the future value. Future value is helpful in determining what overall impact the investment will have compared to other options. The return of investment is the equivelent rate of return for the investment and therefore in our case we shouldn't invest anything below $4 \%$ or the money would be earning less than in other investment vehicles. 

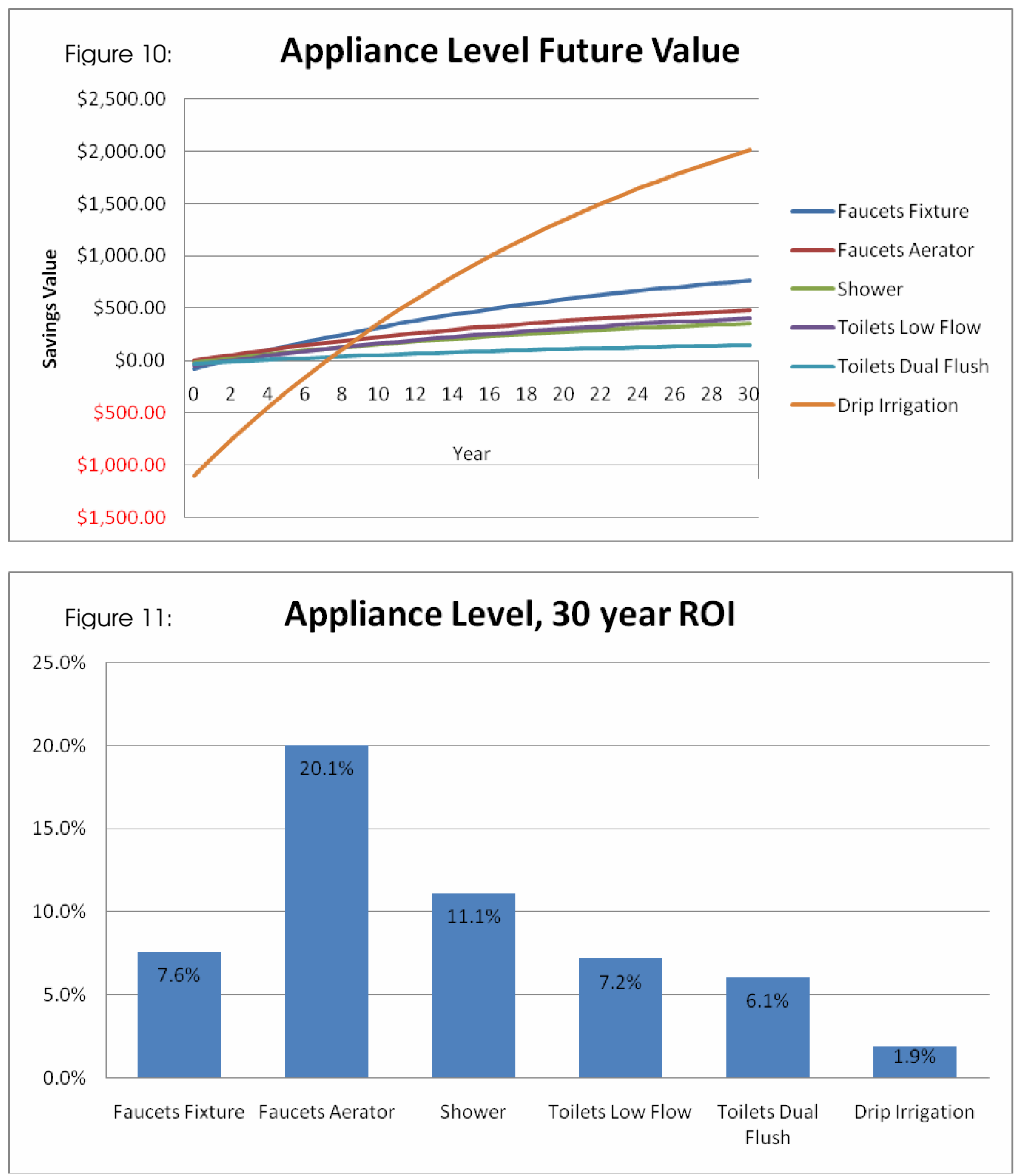

These two charts reveal interesting results. For example, even though irrigation has the largest water usage and also the largest initial investment, the payoff of irrigation systems is significantly lower. 


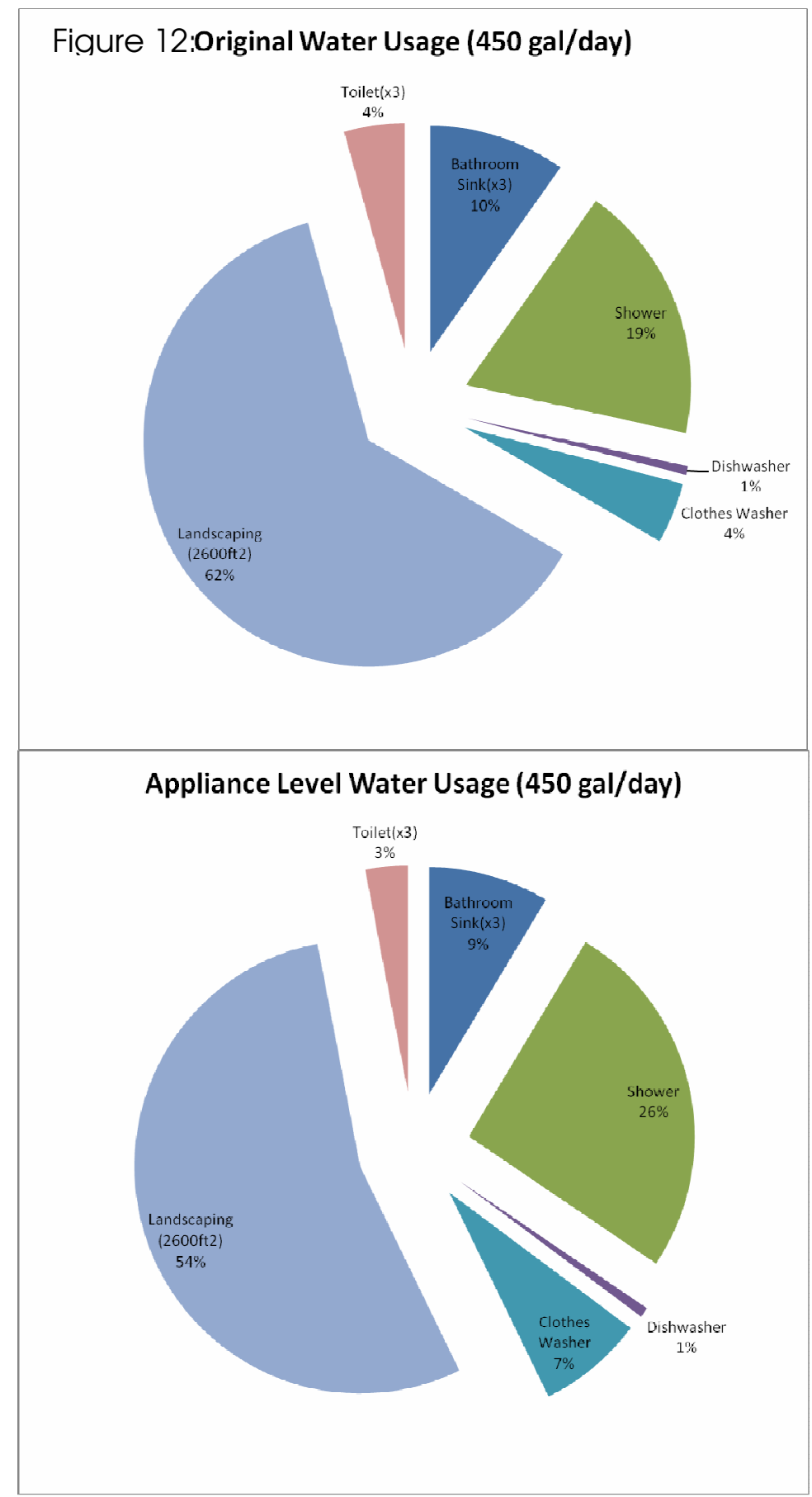

What this all means for the appliance level system in a residence is that regardless of available disposable income, any money allocated to appliance level water conservation will result in economic profitibily, in less than 5 years typically (less 
than 10 with landscaping). As an interesting note, drip irrigation in this case doesn't save the estimated $50 \%$ water because of the lack of available grey water. 


\section{Grey Water Level Systems}




\section{Grey Water Introduction}

This section will explore a concept known at "down-cycling of water". This method of water conservation increases the effectiveness of the water brought on site by allowing it to go through several stages of use. After initial use, the water is referred to as grey water, which is non-potable but still viable in low risk uses in a home. This grey water comes from the drains of sinks or showers and is not fit for drinking but can be used in other ways in the home. Primarily this partially contaminated (not suitable for human consumption) grey water is used in toilets, laundry machines, and landscaping.

To be more specific on grey water, the California code defines it as follows:

1602.1 Graywater [HCD 1] Pursuant to Health and Safety Code Section 17922.12, "graywater" means untreated wastewater that has not been contaminated by any toilet discharge, has not been affected by infectious, contaminated, or unhealthy bodily wastes, and does not present a threat from contamination by unhealthful processing, manufacturing, or operating wastes. "Graywater" includes wastewater from bathtubs, showers, bathroom washbasins, clothes washing machines, and laundry tubs, but does not include wastewater from kitchen sinks or dishwashers.

The other type of water in residential use is "black water". This water comes from the toilet or kitchen sink that contains high levels of solids, bacteria or other chemical contaminants, making it not fit for use in the home. This is generally hazardous water and must be treated in a treatment facility to ensure public safety and avoid the water getting into direct contact with occupants or contaminating sources of water such as streams or the water table. Care must be taken to separate these three different water types from contaminating each other and endangering residents, as the main concern is human safety.

\section{Code Concerns and New Revisions}


Currently in the United States there are many code restrictions relating to grey water. In the target area of this project, it wasn't until the water crisis in 2009 that Callifornia legislature allowed grey water for everyday use. Currently there are many standards of use and outlines that relate to occupant safety. for example, codes currently limit deployment areas to those that are non-reachable by occupants; this includes such systems as drip irrigation where there is subterranean absorption. Code also currently requires strict storage and usage standards. Residential grey water systems must be designed to completely consume the produced grey water every day to prevent bacterial growth in storage. This means there are minimum requirements for dispersion to prevent contaminated water as well as limitations on storage periods before down cycle usage. This is to prevent possible grey water contaminants from growing or festering in storage, increasing the safety risk.

\section{Potable Only Systems}

In a grey water system, not all devices can use the potentially contaminated secondary water. Certain functions in a site require clean water to maintain a human safety factor. These systems typically are those associated with direct human contact such as showers and faucets or are in food related areas such as the kitchen. In these systems, potable water is required for two basic functions: consumption and cleaning. In a residential down cycling system, available grey water is calculated from the output of specific devices such as sinks and showers. In the below calculations we are also Table 9: Grey Water: Potable assuming that our greqavateatsigstem is in conjunction with previous appliance level systems. 


\begin{tabular}{lllll}
\hline Total Device & Sinks & Showers & Other & Total Potable Use \\
\hline Total gal/day & 20.5 & 61.2 & 20.3 & 102.0 \\
\hline
\end{tabular}

For our scenario the $102 \mathrm{gal} /$ day is a critical number for grey water calculations for it represents the total available grey water on site and it means that we only need $102 \mathrm{gal} /$ day of onsite potable water without major lifestyle changes. This is drastically different than the $450 \mathrm{gal} /$ day total use predicted before the appliance level and 275 gal/day total use after appliance level fixes.

\section{Landscaping}

The largest feasible application of untreated grey water is for landscaping. With landscaping taking half of the current potable water, down-cycling water into landscaping would halve potable water usage overnight. It is also a well known grey water solution, having been accepted even in current California water code.

There are however a few main concerns with using grey water in a landscaping system. Because of the nature of the grey water and its solid contaminants, we cannot assume the same homogenous characteristics that we get from potable water. This is a major concern for outdated drip irrigation systems, as they rely on pores in the hose material to allow water to trickle through. With the introduction of waste particles into the water, the only solution for compatibility with drip irrigation is to filter the contaminated water. This means that we have to divide the landscaping into two different systems, filtered grey water with a drip system and standard above ground watering method. 
For the filtered system, we must first factor in the cost of the filtration system. The system itself averages $\$ 650-\$ 800$ and is expected to last the length of the average home (around 30 years in this case). There are two different ways these systems function: as a direct filtration system (mechanical) and through a living machine (environmental). For the following calculations it is assumed that the overall irrigation system is installed with the filtration system so that the two types of landscaping systems Table 10: Grey
can be compartiestaping

$128.5 \mathrm{gal} /$ day need, 120 grey available, 8.5 potable needed over $248 \mathrm{gal} / \mathrm{day} * 365 \mathrm{day} / \mathrm{yr} * \$ 4 / 1000 \mathrm{gal}=\$ 362.08 / \mathrm{yr}$ savings $\$ 1,144$ landscaping cost (previous calculation $)+\$ 750$ filtration $=$ $\$ 1,894$

\begin{tabular}{llll}
\hline Initial Investment & i & Annual Savings & Buyback Period \\
\hline$\$ 1,894$ & $4 \% / \mathrm{yr}$ & $\$ 362.08 / \mathrm{yr}$ & $4.84 \mathrm{yr}$ \\
\hline
\end{tabular}

The second system is the traditional, above ground sprinkler system. There are two major concerns with this system setup: safety and water usage. In this system of delivery with above ground sprinklers, there is a good chance of human contact and potential pathogen transfer, which is currently also banned by California grey water code. With this particular house there is also a concern over the availability of grey water for use with a high volume, above ground system. Because the grey water produced in this house is significantly less than the amount required, we would also have to add potable water to the irrigation system. This means although it is the most Table 10: Grey Water:

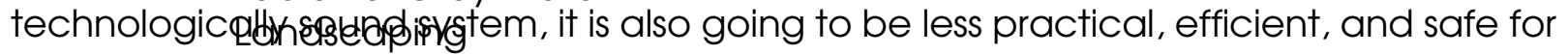
occupants. 
$\left(\$ .50 / \mathrm{ft}^{2}+\$ .30 / \mathrm{ft}^{2}\right) / 2 * 2600 \mathrm{ft}^{2}$ exterior ${ }^{*} 80 \%$ landscape coverage $=$ $\$ 832.00$

$256.5 \mathrm{gal} /$ day need, 120 grey available, 136.5 potable needed over

$120 \mathrm{gal} /$ day ${ }^{*} 365 \mathrm{day} / \mathrm{yr}{ }^{*} \$ 4 / 1000 \mathrm{gal}=\$ 175.20 / \mathrm{yr}$ savings

\begin{tabular}{llll}
\hline Initial Investment & $\mathbf{i}$ & Annual Savings & Buyback Period \\
\hline$\$ 832.00$ & $4 \% / \mathrm{yr}$ & $\$ 175.20 / \mathrm{yr}$ & $4.43 \mathrm{yr}$ \\
\hline
\end{tabular}

After the analysis of these systems it is obvious that the drip irrigation system is the better option, although it has a slightly longer buy back period, its future value makes it a worthwhile investment when in conjunction with safety concerns and overall lessened potable use. This system doesn't affect standard of living for occupants either; with a properly functioning system, grass areas are acceptable for human contact, only concern being edible gardens with fruit/vegetables in direct contact of soil, unlike the traditional above ground system.

\section{$\underline{\text { Toilets }}$}

The second feasible system for grey water usage is toilets. For this system, nearby grey water sources such as sinks feed into the toilet tank to be used when flushing. This is done with secondary piping and an overflow system, which means that grey water is pumped into the tank and the "overflow" continues through the system, in this case to landscaping. The second option, which is better known, is an above tank sink that doesn't require piping but is inconvenient when washing hands. Either system however requires about the same amount of money to install. In the case of new construction, the only additional cost for this system is the piping/overflow or the above tank fixture. 
Table 11: Grey Water: Toilets

7.2 gal/day * 365 day $/ y r^{*} \$ 4 / 1000 \mathrm{gal}=\$ 10.51 / \mathrm{yr}$ savings

\begin{tabular}{llll}
\hline Initial Investment & i & Annual Savings & Buyback Period \\
\hline$\$ 85.00$ & $4 \% / \mathrm{yr}$ & $\$ 10.51 / \mathrm{yr}$ & $7.15 \mathrm{yr}$ \\
\hline
\end{tabular}

This system is not the best investment on a financial basis, but even with the above tank system it has the benefit of low lifestyle impact.

Summary

Below is a schematic showing how water works through the system divided into individual areas of the house and into the different systems. 


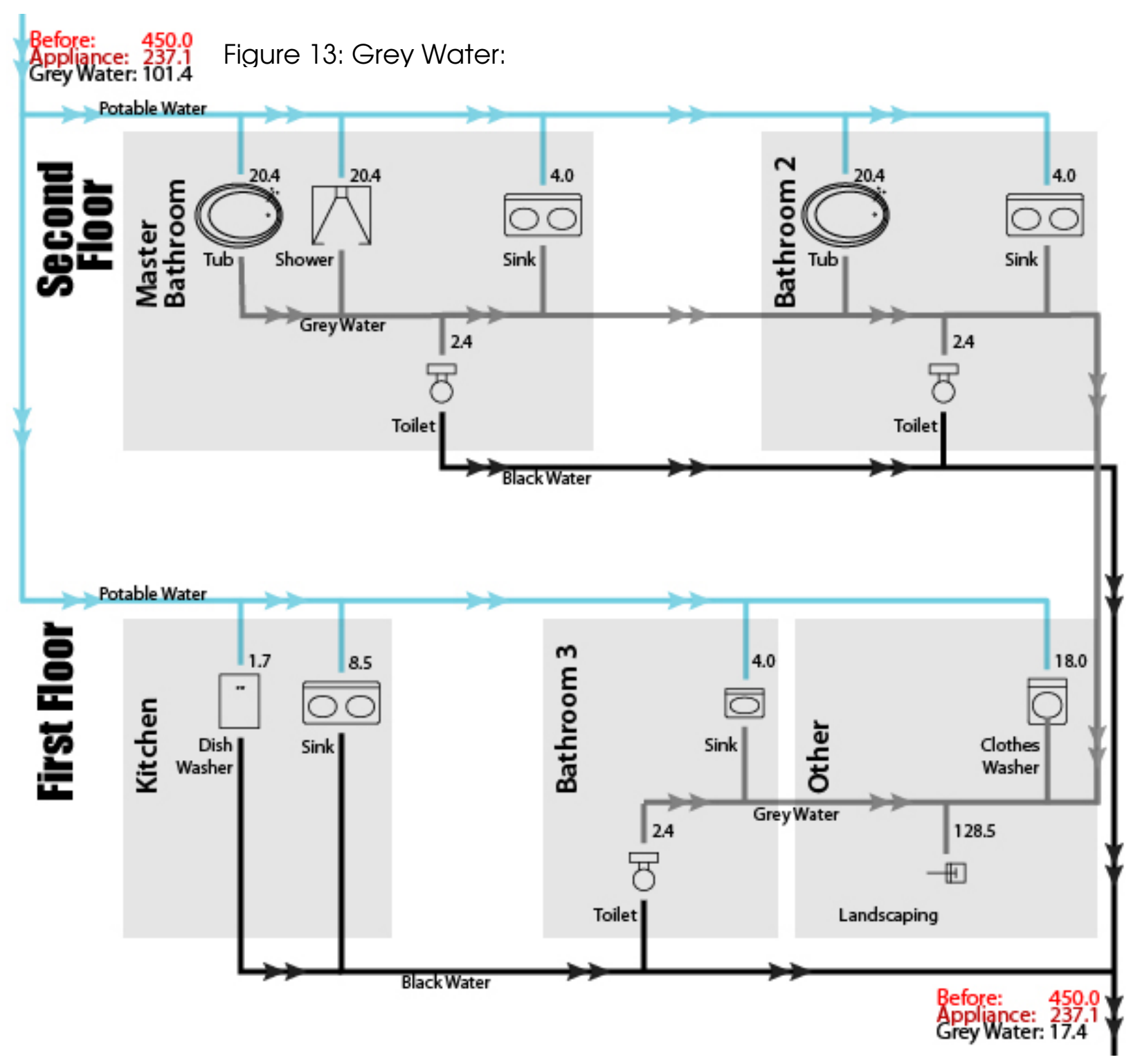

Below is a a composite analysis including the exponentially increasing water rates over the next 30 years. Even with this approach and in an area with cheaper base level water the analysis reveals that all investments are paid back in 11 years, significantly longer than the foreseeable life of those systems even with maintenance costs. With these systems there is also very low lifestyle impact which is critical for adoption of these systems.

Table 12: Grey Water: Summary Landscaping (Drip) 
Water Saving! Initial Cost FV

$248.0 \mathrm{gal} /$ day $\$ 1,144.0 \mathrm{O}$ \$ $17,395.3 \mathrm{~N} / \mathrm{A}$

ROl: 5 year 10 year 30 year Buyback

Landscaping (Traditional)

Water Saving: Initial Cost FV

ROI: 5 year 10 year 30 year Buyback

$120.0 \mathrm{gal} /$ day $\$$

832. $\$$ 8,149.3. N/A

\begin{tabular}{l|l|l}
$-8.06 \%$ & $7.90 \%$ & $9 \mathrm{yr}(\mathrm{s})$
\end{tabular}

\section{Toilets}

Water Saving؛ Initial Cost FV

$7.2 \mathrm{gal} /$ day $\$$

85.C $\$ \quad 455.2$ N/A

ROl: 5 year 10 year 30 year Buyback

\begin{tabular}{|l|l|l|l|}
$455.2 \mathrm{~N} / \mathrm{A}$ & N/A & $5.75 \%$ & $11 \mathrm{yr}(\mathrm{s})$ \\
\hline
\end{tabular}

Below is a chart dictating one of the most crucial investments for water savings

(the landscape system) and its future value over the course of the 30 year period.

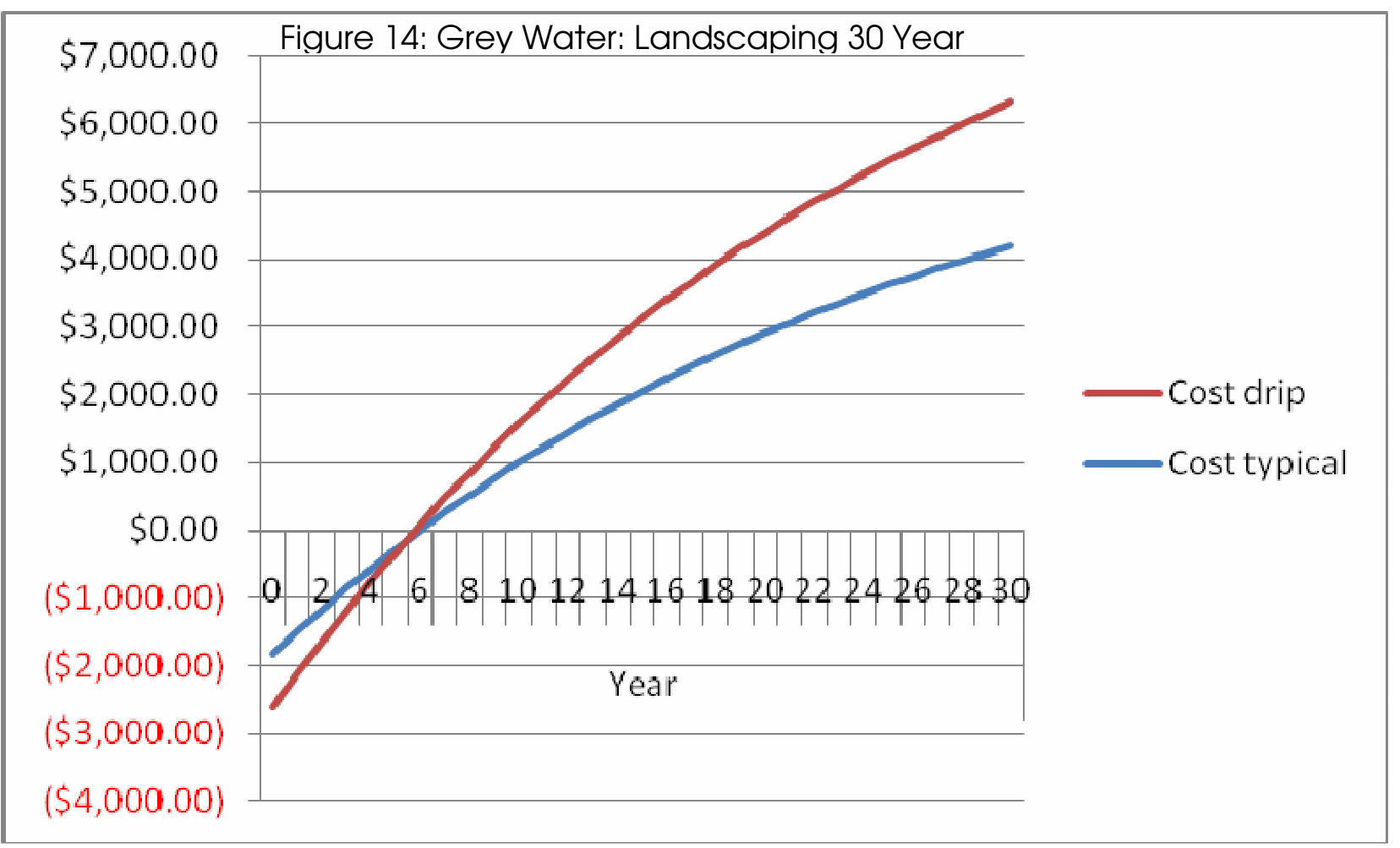


These charts show the breakdown of water levels usage in the home after the grey water system is taken into account.

Figure 15:

\section{Potable Breakdown}
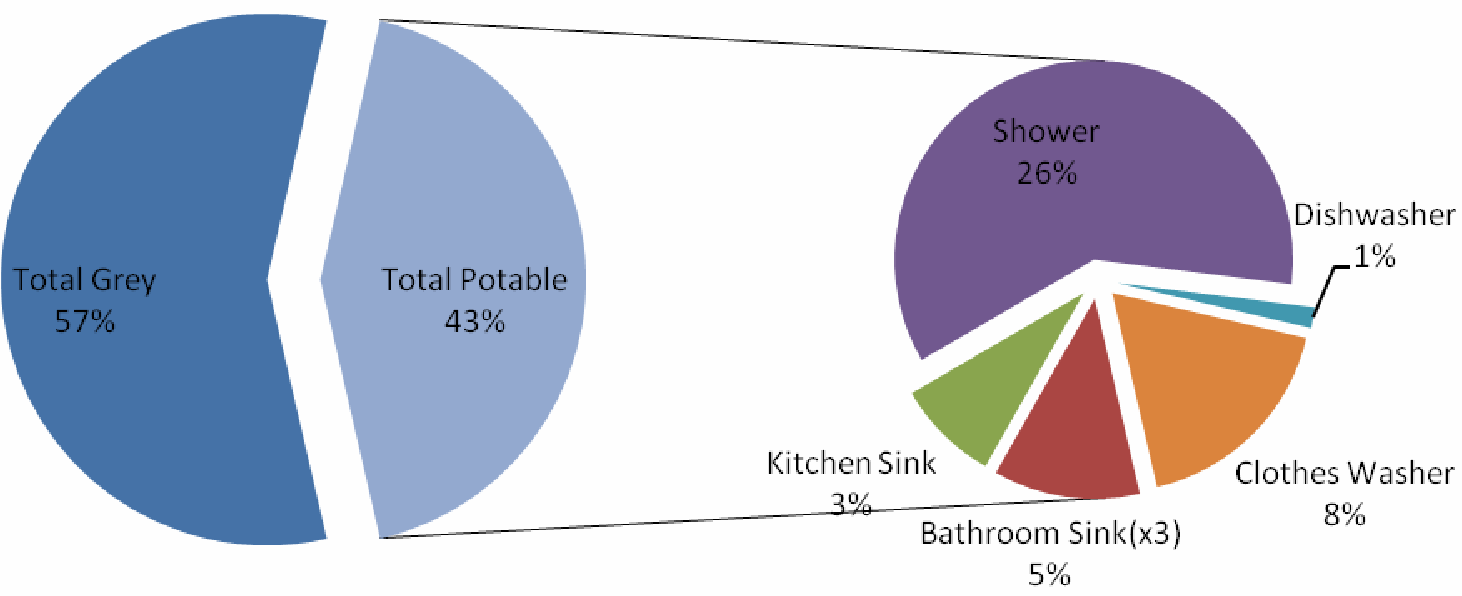

Grey Water Breakdown

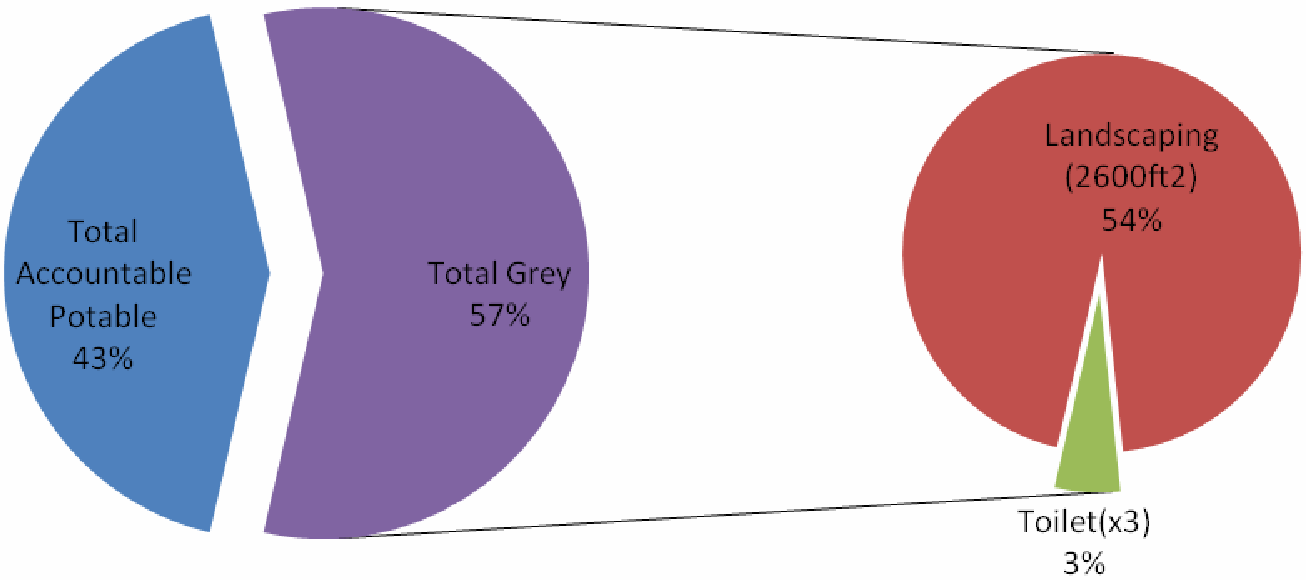


Water Catchment 


\section{$\underline{\text { Introduction }}$}

Water catchment is an innovative way to not only decrease reliance on potable water but to also engage the building site. In areas of heavy rainfall or a serious lack of potable water, rainwater catchment is one of the most viable ways to relieve or augment water conservation strategies. It has been used in heavy rain areas such as Portland, Oregon for many years (Adams, Sam, and Susan Anderson, 201 1). It is less often used in standard and low water areas such as this project site; however it still might be a viable option when the water crisis becomes more intense.

\section{$\underline{\text { Concerns }}$}

There are a few major concerns with rainwater collection, similar to grey water concerns, mostly involving public safety concerns. There are many pathogens and issues that can be developed in a poorly maintained or set up rainwater catchment. These major health contaminants are primarily "... algae, air pollution, bird excrement, and (sediment)" (Pushard, 2011). There are also code concerns as currently only external water use is approved for rainwater catchment without permit.

\section{$\underline{\text { Catchment }}$}

Catchment is the first step in a rainwater harvesting system and sets the available water for onsite use. Typically there are two different catchment options on site for residential: ground and roof. Ground systems are typically the simplest installation but the hardest to control and use later. There is no viable option for redirecting the water to storage or interior usage. The second system is the most flexible 
and also has the advantage of engaging the seldom used roof area of a home. The only limitations to these systems for this project, are the size of the collection area (typically roof) and ability for onsite storage in our new construction.

A major advantage to both of these systems is that catchment requires almost no money upfront. The only additional cost would be to upkeep the roof and for the secondary plumbing required to separate potable and this high quality grey water. This additional plumbing is no more than the above grey water system so we can assume that catchment requires only minimal maintenance cost similar to that of standard water systems and standard roofs.

\section{Storage}

A crucial part of rainwater catchment systems is the design and location of the storage of the water before use. For more completed systems, storage is essential for water usage between rainy periods and when indoor appliances cannot use the caught water immediately. For storage there are two main options for such systems.

Below ground storage is advantageous in new construction but has some major downfalls. The price is higher than above ground systems because of the extra construction needed. This underground storage cost translates to about $\$ 1 /$ stored gallon of captured water (Gelt, 2011). These underground tanks are generally made

from steel or concrete and have a reasonably long lifespan if maintained properly. The main issue with these tanks is maintenance because of its underground location if issues arise with the tank involving contaminants or leaks. 
The other available rainwater storage system is above ground. This lacks the visual obscurity element of the below ground systems but has other properties that make it advantageous. The above ground system is easy to maintain and is significantly cheaper, around .07 cents/gallon for storage (Gelt, 201 1). These systems are made of out similar materials but also require a lid to prevent evaporation. On sites where tank visibility is not an issue, this system is definitely the preferred method.

\section{Available Systems}

The simplest system of rainwater catchment is directly from collection surface to landscaping. This is the code acceptable version of rainwater collection with no permit. This also requires no storage so it is the cheapest system but in our case it is not practical for analysis because it serves the same function as the water down cycling in our residence.

Basic system setup for our area is based off of roof size and climate for sizing. The first assumption is that the roof area of this site is entirely used for collection ( 1100 sq.ft.). It is also assuming continuing climate trends in Irvine of 14 inches of rainfall a year, and longest dry period without rain being 30 days. With a small factor of safety the calculated collection will be around 5000 gal/year or 14 gal/day (Benjamin, Reynolds, Grodzik, and Kwok, 2009 page 540). In this system with a potential 45 day period of drought, the cistern will be designed accordingly to hold 2100 gallons.

\section{Catchment to Internal Grey}


The next system in complexity is that of simple storage of rainwater and internal use. This requires either an above or below ground storage system.

Table 13: Catchment: To Internal spepnd story tank

Without filtration the process can feed into showers and the clothes washer.

$14 \mathrm{gal} / \mathrm{day} * 365 \mathrm{day} / \mathrm{yr} * \$ 4 / 1000 \mathrm{gal}=\$ 20.44 / \mathrm{yr}$ savings

\begin{tabular}{llll}
\hline Initial Investment & i & Annual Savings & Buyback Period \\
\hline$\$ 147.00$ & $4 \% / \mathrm{yr}$ & $\$ 20.44 / \mathrm{yr}$ & $6.45 \mathrm{yr}$ \\
\hline
\end{tabular}

Ground level tank

This system needs an added pump to pressurize the water.

$14 \mathrm{gal} / \mathrm{day} * 365 \mathrm{day} / \mathrm{yr}{ }^{*} \$ 4 / 1000 \mathrm{gal}=\$ 20.44 / \mathrm{yr}$ savings

\begin{tabular}{llll}
\hline Initial Investment & i & Annual Savings & Buyback Period \\
\hline$\$ 447.00$ & $4 \% / \mathrm{yr}$ & $\$ 20.44 / \mathrm{yr}$ & $16.02 \mathrm{yr}$ \\
\hline
\end{tabular}

Below ground tank

$14 \mathrm{gal} / \mathrm{day} * 365 \mathrm{day} / \mathrm{yr} * \$ 4 / 1000 \mathrm{gal}=\$ 20.44 / \mathrm{yr}$ savings

\begin{tabular}{llll}
\hline Initial Investment & i & Annual Savings & Buyback Period \\
\hline$\$ 2400.00$ & $4 \% / \mathrm{yr}$ & $\$ 20.44 / \mathrm{yr}$ & $44.36 \mathrm{yr}$ \\
\hline
\end{tabular}

Because of the small roof collection area, most catchment systems are not short term feasible. The above ground tanks that are feasible might have hidden costs such as being unattractive or needing strengthening in structural support members for the second level system. As a result, planning on water catchment, smaller tanks might be just as efficient when supplementing an existing potable water system.

\section{Catchment to Internal Potable}


For this system, the amount of captured water isn't high enough to warrant treatment for potable use (we are not lacking potable water and the amount of captured water is not sufficient to supplement existing potable on site). For larger sites or those with higher annual rain, catchment will definitely be a viable potable water option much like ground wells or springs.

Filters are an important part in all further treatment processes. With sediments in the water there are issues with quality and health concerns. Filters are usually done with a couple of passes and different scaled filters to remove debris from the water that might exist on the collection surfaces. These filters are generally not done in a natural fashion and instead are disposable or replaceable filter cartridges costing around $\$ 40$ total, and \$3-5 each to replace (Errson, 2006). These filters must then be used in conjunction with other disinfection procedures (below) to create potable water.

One of the most common methods of disinfection in public water systems is chlorine, being used "...by over $98 \%$ of all U.S. water utilities that disinfect water" (Calomirisand Christman, 1998). Chlorine destroys microorganisms through a complicated molecular process and renders the water safe. There are a few major issues with chlorination, in particular if the chlorine levels are wrong. If not monitored carefully chlorine reacts with organic materials in the water to create trihalomethanes such as chloroform which can cause occupant harm (Pushard, 2010). Carbon filters are usually implemented afterwards to mediate the taste and smell of the chlorinated water, while filters are crucial in stopping the organics pre chlorination. The stand method of chlorination disinfection requires adding 1 quart of bleach for 400 gallons of water raising the chlorine concentration to 200 milligrams per liter (Herman and 
Jennings, 1996). This process is inexpensive overall but requires heavy user interaction, whereas commercial systems cost upwards of $\$ 300$ for automated systems (Chem Feed Systems, 2011).

Another system capable of killing microorganisms is the ultra violet light system, also known as UV light sterilizer. This uses concentrated light to rupture potentially harmful cells and render them inert. This system is usually capable of processing 10 gallons of water/min which is sufficient for a residence of similar size to this case study (Errson, 2006). These systems are in the same price range as some of the others, requiring $\$ 350$ for install and more for replacement bulbs and required energy for the unit (Errson, 2006).

A more advanced system of decontamination is referred to as reverse osmosis. It works by pushing water through a membrane that removes the smallest of particulates and microorganisms. These systems are more advanced and cost more around $\$ 600-$ $\$ 900$ for an in home system (Herman and Jennings, 1996). They usually don't have perfect filtration and many systems produce 1 part potable water and 2 parts grey for every 3 put into the system.

The least cost effective sanitization system requires high amounts of energy and effort and is referred to as the distillation system. This system uses large amounts of energy to boil water and collect the water vapor condensate for drinking water. This is a fairly expensive system to install and run, about $\$ 250-\$ 1450$ without maintenance and upkeep (Herman and Jennings, 1996). This is the least compatible system for large scale potable water usage in a home.

\section{Summary}


For this site and its limited annual rainfall, catchment is a less effective means of water conservation. Although the buyback period is typically within the lifespan of the building (excluding rebates and utility discounts), it is still less viable than other conservation efforts. It is however an acceptable tertiary investment, when grey water and appliance level water saving systems have already been invested in. Below is a chart showing the schematic design with the rainwater catchment system supplementing an existing appliance and grey water level system.

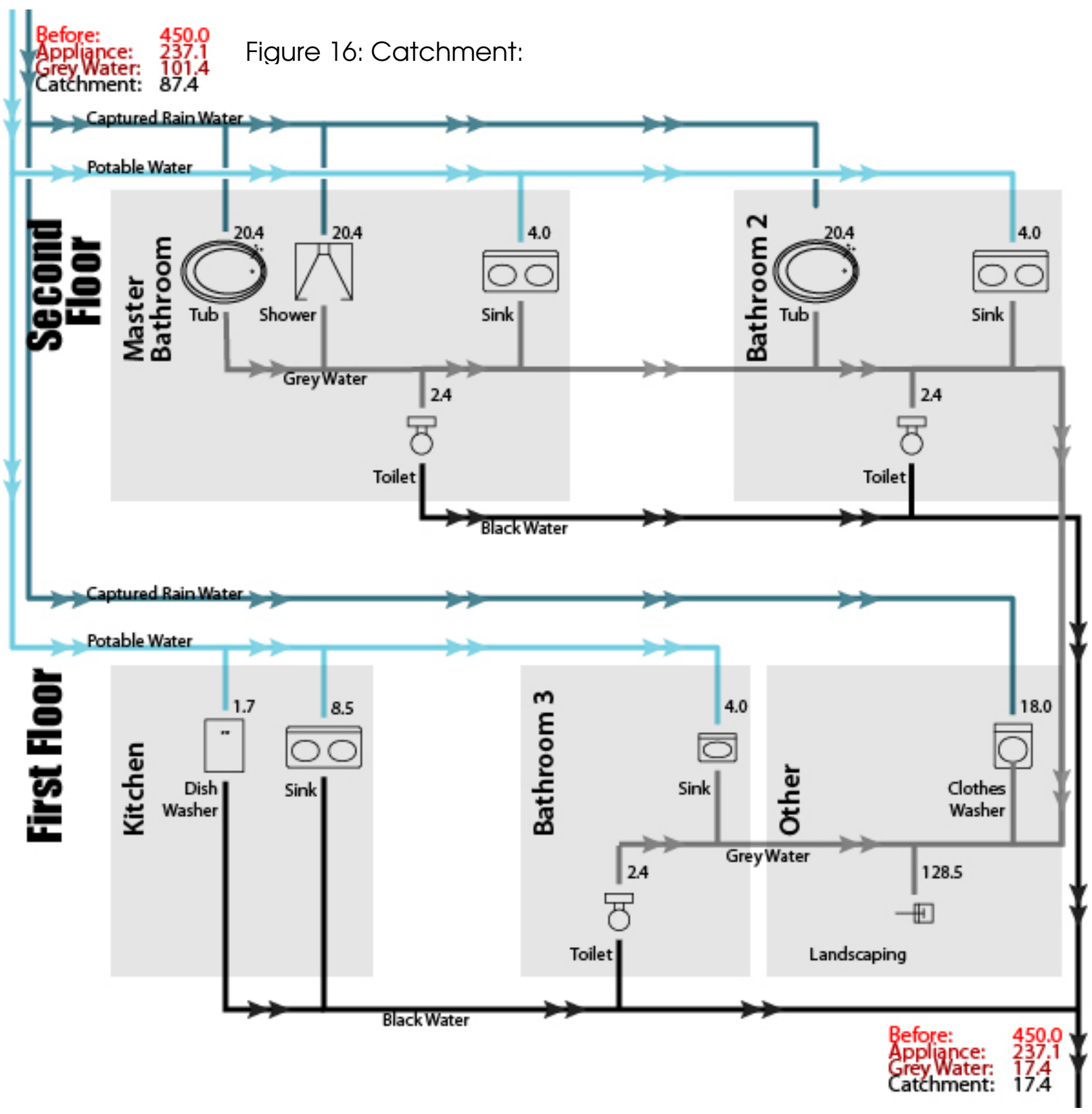


On-Site Water Treatment 
$\underline{\text { Introduction }}$

A crucial component of water conservation on our residential site is end product. This section deals with black water, a waste water byproduct from use normally piped to larger infrastructure. Typically this type of water is handled offsite but there are still costs and social implications to the user. There is an available option to keep black water onsite for treatment and dispersion into the environment which is currently not being taken full advantage of in most residences.

\section{Typical Black Water Treatment Methods}

Currently there are only a handful of options for where black water goes after being used on the site. The first most popular and widely accepted system is the city sewage system, where black water is taken off site and treated in large quantities before returning back into the water system. These citywide water systems typically do not return water back into the potable system directly, but instead let it percolate through nature (filtration through the ground and the different wetland systems) and recapture it elsewhere. In areas where this is not applicable there are onsite septic systems, where waste water is stored and partially digested by microorganisms. After partial digestion and heavy separation of solids from water, the liquid layer of effluent is discharged into a leach filled back into nature (Blackwater and Water Recycling, 2007). These tanks usually don't have to be emptied if maintained and functioning properly.

\section{Disposal Alternative}


As an alternative to the above traditional systems, composting toilets might be implemented. These systems have major advantages, but also require heavy lifestyle changes. Immediately after installation, there is a major decrease in water consumption as it is no longer needed for flushing toilets. This also eliminates black water issues in a house, leaving only usable grey water systems to worry about. Without a sewer hookup (where applicable), users also save major costs as well as decreasing the burden on current treatment infrastructure. In our case study home, the water savings would be $7.2 \mathrm{gal} /$ day instantly by removing water demand on toilets. In addition to that we would also be freeing up the equivalent in grey water to be able to therefore reduce potable water usage. These toilets are also significantly cheaper than a septic system costing about $\$ 1300$ which can be from $25 \%-75 \%$ of the septic alternative. This means that instead of a septic system, composting toilets are always a viable investment immediately. Below we are assuming there is no savings by reducing utility cost (sewer hookup) which would also make a significant impact on the buyback period.

Table 14: Black Water: Composting Toilets
i6 gal/day* 365 day/yr * \$4/1000gal $=\$ 23.36 /$ yr savings

\begin{tabular}{llll}
\hline Initial Investment & i & Annual Savings & Buyback Period \\
\hline$\$ 1300.00$ & $4 \% / \mathrm{yr}$ & $\$ 23.36 / \mathrm{yr}$ & $29.86 \mathrm{yr}$ \\
\hline
\end{tabular}

Although the composting toilet seems economically viable, especially compared to a septic installation, it is not readily used primarily because of the impact the system has on the occupant's daily lifestyle. The most obvious of social implications is the impact of using a different style of toilet. With a composting toilet, there is some smell and off gas associated, even though in the recent past it was drastically decreased. Aside from that, occupants must also be aware of what chemicals and 
compounds they put into the body, as some might damage the ecosystem of the composting toilet (many preservatives cannot be broken down by the bacteria for example). Care must also be taken when cleaning the toilet and performing maintenance not to alter the toilet's internal ecosystem (by adding bleach for example). This added burden in conjunction with higher maintenance means that it will be less likely to be adopted by residential occupants.

\section{Alternatives Systems of Treatment}

Counter to the idea of onsite disposal of black water is the treatment option. For this system there are two main opposing approaches: the living machine system and more complicated and larger scale toilet to tap inspired systems. Both work to achieve higher quality water for reuse in a residence, usually as grey water and infrequently as potable water, due to the inherent health and maintenance concerns.

The living machine system is already in practice in cutting edge case studies at IslandWood in Seattle, WA. The living machine takes natural filtration processes found in nature and duplicates them on a small scale to purify water. The system filters out water and then goes through a multi-stage treatment process that then removes microbes and other possible contaminants from the grey water. According to the EPA, living machines requiring a greenhouse are $10.1 \%-10.7 \%$ less costly than traditional system, and without a green house $17.5 \%-18.4 \%$ cost reduction in the low/mid range. They do however cost about 2.5 times as much as offsite treatment methods such as 
sewer systems (Kerryg, 2011). This means that cost is around $\$ 2000$ or so for setting up a small scale system like the one needed for this site. The treatment stages for the living machine are as follows:

1. Stage 1 - Anaerobic Reactor: The purpose of this stage is to initially remove most of the solids and many of the associated bacteria (referred to as $\mathrm{BOD}_{5}$ ). This step is similar to the operation of a septic tank and is usually designed similarly. The separation is done through two different systems: bacteria digestion of solid organics and differential settlement. Due to the similarities between this system and a traditional septic tank in methods and function, they share common design features. The tank is usually underground and with the quality of the water and the separation process odors have to be controlled.

2. Stage 2 - Anoxic Reactor: After the solids have been initially removed from the water, the water is then treated in a different manner with the addition of oxidation (aeration). This stops the anaerobic reaction and causes the development of different types of microorganisms. These microorganisms are designed to further remove $\mathrm{BOD}_{5}$, nitrate and to encourage floc-formations. Floc forming bacteria/microorganisms take dissolved particles in the water and convert them to settlement that can be filtered or treated out of the water. This reactor is also partially fed by step 5 biosolids and nitrified water from step 4 to supplement the carbon necessary for denitrification. 
3. Stage 3-Closed Aerobic Reactor: This continues in the reduction of $\mathrm{BOD}_{5}$ within the water while removing odorous gasses. These gasses are diffused and absorbed by a planted layer typically at the top of the tank that acts as a biofilter.

4. Stage 4-Open Aerobic Reactors: This process is designed to reduce the $\mathrm{BOD}_{5}$ to more appropriate levels and complete nitrification (converting ammonium to nitrate nitrogen). This is done through a densely vegetated planted layer at the top and the associated insect/microbial colonies supported by the vegetation. When discussing a living machine, this is normally the most visually prominent section of the treatment process, although one of the most delicately balanced ecosystems.

5. Stage 5-Clarifier: This is the final solid separation system in the wastewater treatment, removing those solids for reprocessing or disposal. Reintroducing new organic solids such as algae in this system is one of the biggest concerns and steps are taken to prevent organic growth. Many times ultraviolet treatment is implemented here as well.

6. Stage 6-Ecological Fluidized Beds: This is the final filtration process of the water that reduces particles and $\mathrm{BOD}_{5}$ to acceptable levels. This is done through a gravel percolation process much like the movement of groundwater in nature (this is also not allowed in California Code).

Figure 17: Black Water: Living 


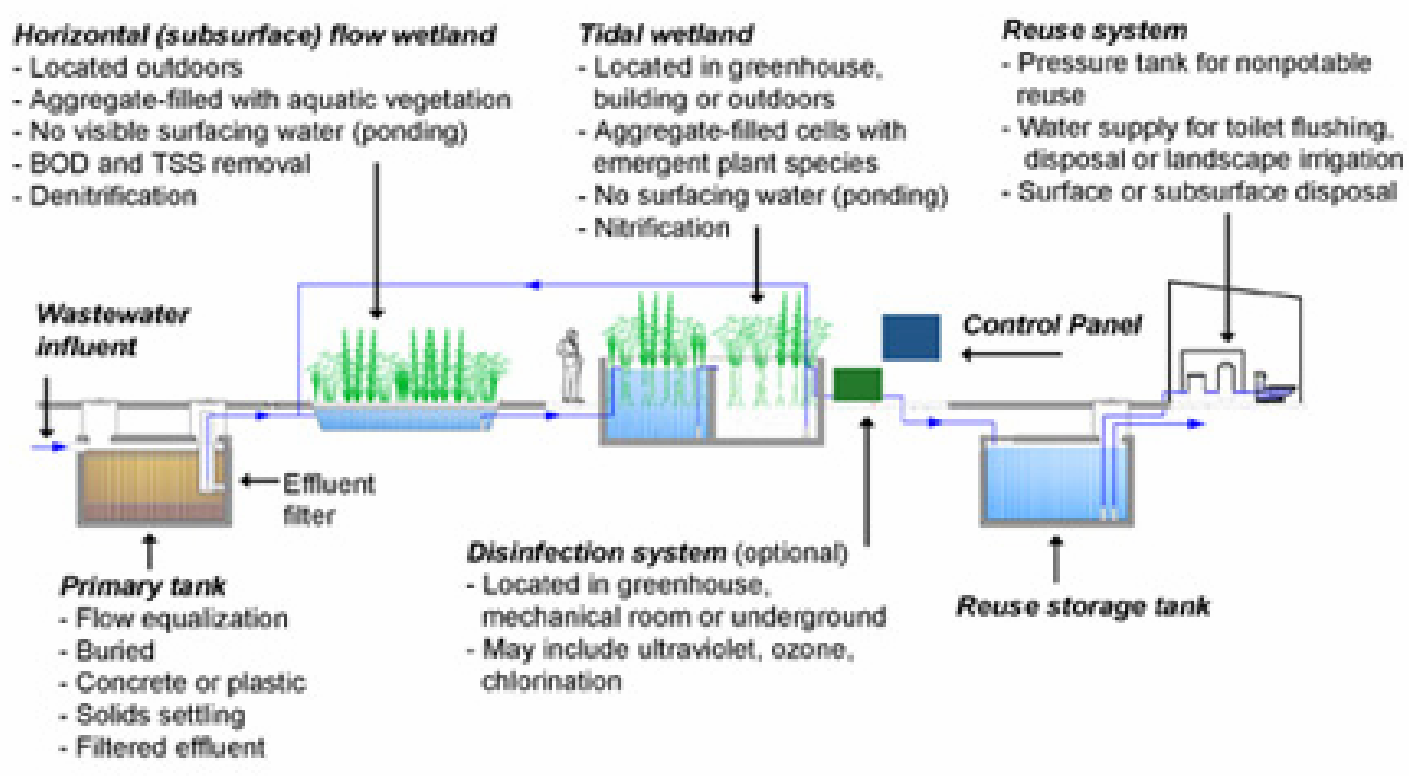

orr

ell

ater Technologies (http://tinyurl.com/3mzwlht)

Table 14=5: Black Water: Living Machine

$70.8 \mathrm{gal} / \mathrm{day}{ }^{*} 365 \mathrm{day} / \mathrm{yr}{ }^{*} \$ 4 / 1000 \mathrm{gal}=\$ 103.37 / \mathrm{yr}$ savings

\begin{tabular}{llll}
\hline Initial Investment & i & Annual Savings & Buyback Period \\
\hline $\mathbf{2 0 0 0 . 0 0}$ & $4 \% / \mathrm{yr}$ & $\$ 103.37 / \mathrm{yr}$ & $14.61 \mathrm{yr}$ \\
\hline
\end{tabular}

The other method is a mechanical alternative to natural processes, but acts in a similar fashion. The water sediment is filtered out through a multi stage process before heading into a reverse osmosis system that filters out salts, viruses and pesticides. The water is then "disinfected with a mix of ultraviolet light and hydrogen peroxide," leaving it drinking safe (Lance, 2009). This method is referred to as toilet to tap and holds a 
negative stigma among the popular. The negative connotation of toilet to tap is the main obstacle to overcome for practical onsite black water treatment.

With tap to toilet there are a few companies making headway in developments and application for residential solutions. A popular system for residential treatment was developed by Orenco and is referred to as a pump system, producing grey water from black for onsite use. This package currently retails for $\$ 1,300$ and is installed in conjunction with a septic tank system. The second system is much more of a rigorous filtration and disinfection and runs significantly higher in cost as it is a case-by-case Table 16: Black Water: Grey Mechanical invoice (some as high as $\$ 17,000$ ).

Low End Mechanical System (Non Potable, No Maintenance)

$70.8 \mathrm{gal} / \mathrm{day} * 365 \mathrm{day} / \mathrm{yr} * \$ 4 / 1000 \mathrm{gal}=\$ 103.37 / \mathrm{yr}$ savings

\begin{tabular}{llll}
\hline Initial Investment & i & Annual Savings & Buyback Period \\
\hline$\$ 1300.00$ & $4 \% / \mathrm{yr}$ & $\$ 103.37 / \mathrm{yr}$ & $10.39 \mathrm{yr}$ \\
\hline
\end{tabular}

These systems both are economically viable but require much unforeseen maintenance that is heavily area dependent. These systems must be designed on a case by case basis because of code restrictions and limitations of different areas that will change the physical system setup as well as involved costs, such as sewer hookup savings. These systems are cutting edge on the user level implementation in residences and might improve over time with greater public adoption.

\section{Summary}

Between the three systems of composting toilet, living machine treatment, and mechanical black water treatment, all are economically viable within the lifespan of 
the house but at the cost of living adjustments. The two black water treatment methods are the most economically viable but both systems require maintenance and careful monitoring which many residents might not be willing to do. Until the system becomes more self sufficient and automated, there might not be much widespread adoption. Concerning cost, the living machine and mechanical treatment system have similar lifespan costs with the included maintenance cost of the mechanical system. In the chart below is the proposed complete system involving catchment, secondary potable hookup and black water treatment. The only water leaving the site is through the landscaping into the natural environment. 


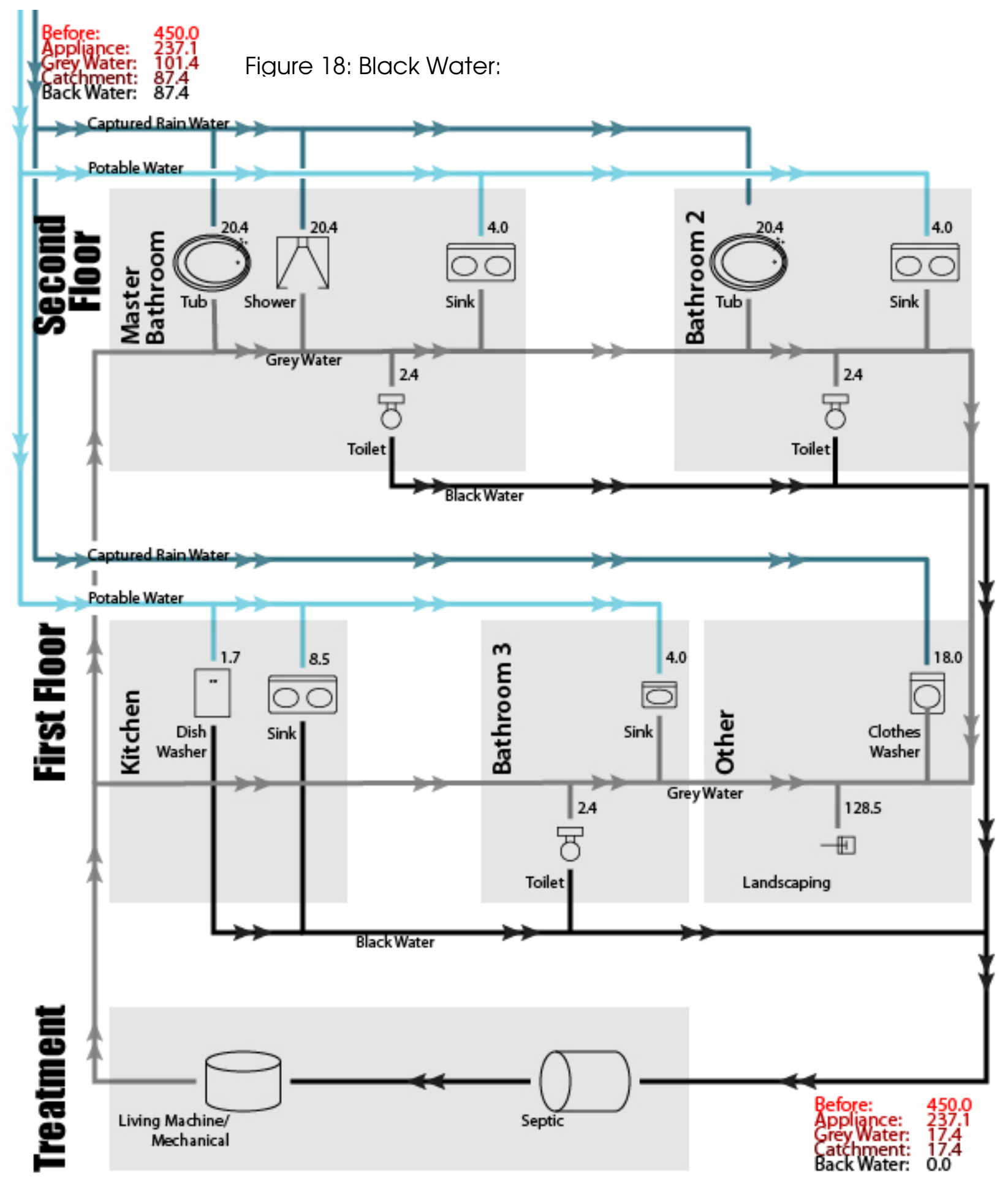




\section{Conclusion}




\section{$\underline{\text { Basics }}$}

On the surface the question regarding the viability of water conservation systems is unclear, but all data in this paper shows that most water conservation systems are not only feasible but a worthwhile investment. If water conservation strategies are applicable in a mid-range residence such as the Irvine case study, that can imply that those same systems might be applicable to other areas where water is even more of a commodity.

\section{$\underline{\text { Cost }}$}

Financial feasibility is typically a major concern whether for developers or homeowners. Most sustainable systems do not excel or become wildly adopted until the financial viability is proven or marketed. Most people are concerned more about personal impact than global impact so finances play a large part in the decision making process involved in investing.

In the decision making process for this thesis, a handful of major assumptions drastically affect feasibility results of the financial decisions. Assumptions were made that with the growing population and ongoing shortage of available water that water prices would continue on their path of exponential growth so a predictive curve was applied to the last 5 years of water data to interpolate future costs for 30 years. Our next major assumption was that maintenance cost varies greatly among products and cannot be accurately implemented into cost analyses, but instead generalized or overaccounted for in predictions. In this paper it has been generally noted when maintenance is known and accounted for and when it is a case-by-case cost. 
$\underline{\text { Impact }}$

These water conservation systems have the ability to impact the entire water infrastructure and on a large scale, alleviate some of the demand on limited potable water. Even though residential construction isn' $\dagger$ the forerunner of water use and waste, it still has a big enough immediate impact to be able to change the current water situation while other sectors catch up. If all new residences applied some of these technologies and principles there may be less concern for the future of water in the United States.

\section{Our Residence}

For the residence in this project, almost every system was viable financially so it was just a matter of how much the occupants were willing to spend to decide where to get the most investment for their money. The basic systems (such as appliance changes in new construction) were economically feasible within a period of 5 years, and as the systems became more complex (such as the black water treatment) buyback period increased. Surprising for this project but not necessarily for this climate was that catchment was almost not financially viable even as a grey water catchment

Table 17: Summary system due to the extraordinarily low rainwater available in the Irvine area. Rated in areas of investment viability:

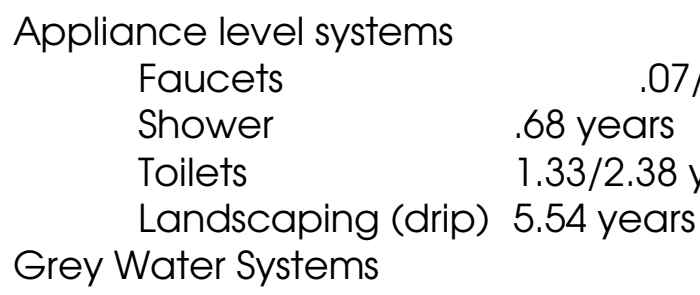




\begin{tabular}{cl} 
Landscaping & \multicolumn{1}{l}{$4.43 / 4.84$ years } \\
Toilets & 7.15 years \\
Catchment & \\
$2^{\text {nd }}$ Story & 6.45 years \\
Ground Level & 16.02 \\
Black Water Systems & \\
Mechanical Filtration & 10.39 years \\
Living Machine & 14.61 years \\
Composting Toilet & 29.86 years
\end{tabular}

All other sections were not viable such as catchment treatment to potable or complicated black water treatment systems to potable.

\section{What this means for Occupants}

This paper in conjunction with the Excel tool acts as an important point of research for occupants. With this information and these tools it is within an occupant's realm of understanding to easing the burden of diminishing water resources. It connects potential water savings options that may be previously unknown to occupants in a cross comparison to other financial investment strategies. This brings water conservation systems into an achievable realm for everyday residential occupants.

\section{What this means for Developers}

For developers this tool has another function as a strong financial calculator. When developing properties this tool may be useful in the planning and marketing stage to explain and warrant water conservation strategies. Using the results of the tool, developers can market the increased cost to buyers and prove the viability of the utility savings over the course of the home's lifespan (around 30 years). This tool will allow 
developers to establish a water investment breaking point for large scale projects to effectively invest in water conservation.

\section{The Bottom Line}

For this particular scenario, any investment into water conservation yields a positive return. With minimal impact on occupants, sustainable water use is attainable. In this case home, an $80 \%$ reduction in water use meant very minor habit changes for the occupants. This is a modest example, as other water conservation techniques could push this reduction even further. This residential selection was limited by many things such as: currently available technology, precipitation levels for rainwater catchment, inability to change specifications of the home, and leaving landscaping standard with current homes (not approaching xeroscaping). Without such limitations, a goal of $10 \mathrm{gal} /$ day potable water use is easily achievable.

Overall this project has an interesting result that should be noted. To achieve the $10 \mathrm{gal} /$ day goal for each occupant is not achievable without user sacrifices. Some of these sacrifices might be as simple as changing out landscaping to xeroscaping but in other scenarios occupants might have to change their standard of living. Lowering that last $19 \mathrm{gal} /$ day for each occupant will require an increase in sustainable knowledge, and an active effort to conserve water. 
Fiqure 19: Excel Comparisons
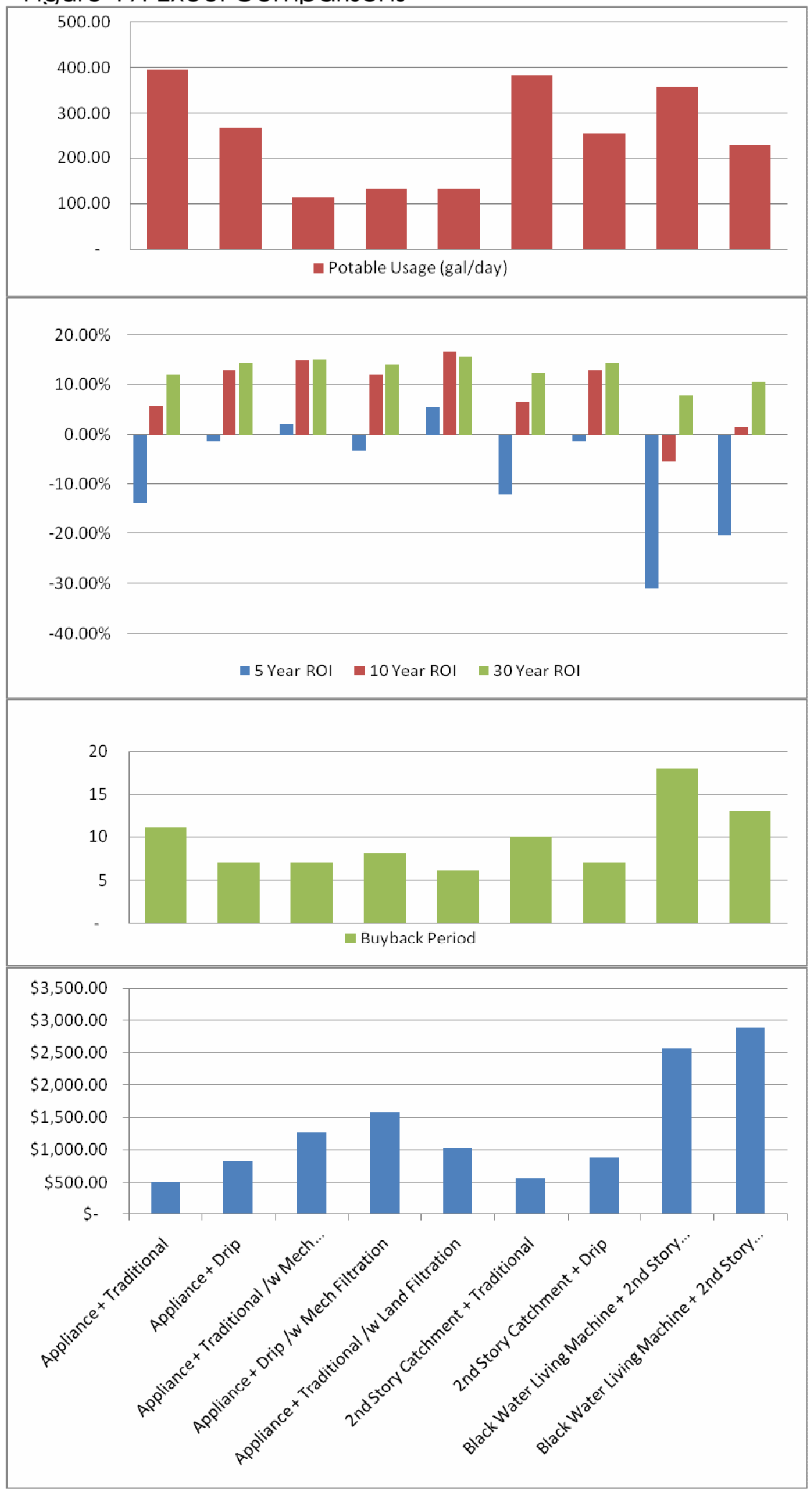
Appendix 


\section{Assumptions}

A. Monetary

a) Strait line payments for buyback period analysis at a water price of $\$ 4 / \mathrm{Kgal}$

b) Assuming a higher current return on investment of $4 \%$ taken from previous 10 years (current is around $1 \%-2 \%$ )

c) Exponential water increase cost (based off of previous 5 years water conservation trends) to be used in the more accurate excel analysis

d) Product costs are taken from McMaster-CARR 2007, Los Angeles catalogue as an average

e) Maintenance and install costs are unknown/unpredictable unless specifically stated in research

f) Utility costs other than water are noted but not taken into account due to the scope of the research (example, high gas/electric use in distillation black water treatment is ignored)

B. Implementation

a) Averages are taking from US Census values of the area as appropriate

b) Daily use values are assuming even use over the course of the year without major fluctuations

c) Systems can be implemented regardless of current code restrictions/criteria

d) User impact (change in standard of living) is not avoided but instead noted in sections

e) Assuming the increased education of users allows the systems to be properly run/maintained 


\section{Excel Calculator}

The Excel calculator performs a very important function in the thesis, making water conservation strategies accessible to users and developers. It allows for more accurate results, taking predicted water costs into account and also being able to compare systems collectively instead of partially independently.

For our house in this thesis development and case study, the water calculator showed that many of the options were more viable on a 30 year buyback period, but less feasible on a short term basis. Surprising items are those like the dishwasher and clothes washer that weren' $\dagger$ financially viable even over a 30 year period. The chart Table 18: Appendix: Appliance below shows a comparison between all appliance level selections.

\begin{tabular}{|c|c|c|c|c|c|}
\hline Appliance & Type & Amount & 5 Year & 10 Year & 30 Year \\
\hline \multirow[t]{3}{*}{ Kitchen Sink } & Original & - & & & \\
\hline & Low Flow & - & $\# N / A$ & $\# N / A$ & $\# N / A$ \\
\hline & Aerator & 1 & $75 \%$ & $50 \%$ & $26 \%$ \\
\hline \multirow[t]{2}{*}{ Dishwasher } & Original & - & & & \\
\hline & Efficient & 1 & $55 \%$ & $24 \%$ & $0 \%$ \\
\hline \multirow[t]{3}{*}{ Other Sink } & Original & - & & & \\
\hline & Low Flow & - & $\# N / A$ & $\# N / A$ & $\# N / A$ \\
\hline & Aerator & 3 & $44 \%$ & $36 \%$ & $22 \%$ \\
\hline \multirow[t]{3}{*}{ Shower } & Original & - & & & \\
\hline & Low Flow & - & \#N/A & $\# N / A$ & $\# N / A$ \\
\hline & Aerator & 2 & $74 \%$ & $50 \%$ & $26 \%$ \\
\hline
\end{tabular}




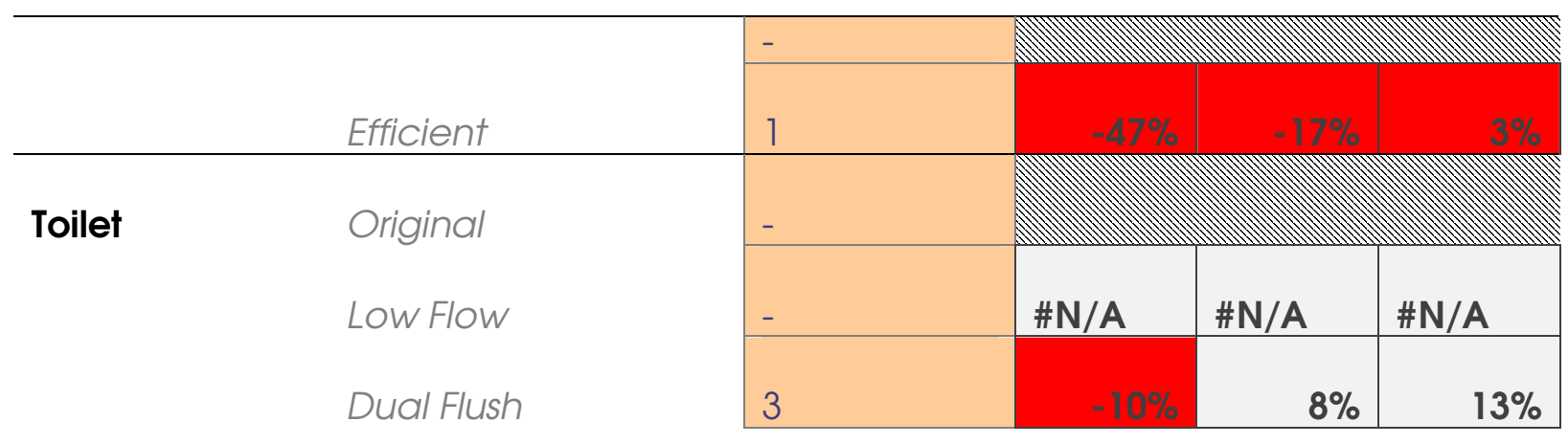

With existing construction systems become much more difficult to make Table 19: Appendix: Appliance Existing economically viable.

\begin{tabular}{|c|c|c|c|c|c|}
\hline Appliance & Type & Amount & 5 Year & 10 Year & 30 Year \\
\hline \multirow[t]{3}{*}{ Kitchen Sink } & \multirow{2}{*}{$\begin{array}{l}\text { Original } \\
\text { Low Flow }\end{array}$} & - & & & \\
\hline & & - & $\# \mathbf{N} / \mathbf{A}$ & $\# \mathbf{N} / \mathbf{A}$ & $\# N / A$ \\
\hline & Aerator & 1 & $14 \%$ & $21 \%$ & $17 \%$ \\
\hline \multirow[t]{2}{*}{ Dishwasher } & \multirow{2}{*}{$\begin{array}{l}\text { Original } \\
\text { Efficient }\end{array}$} & - & & & \\
\hline & & 1 & & & \\
\hline \multirow[t]{3}{*}{ Other Sink } & \multirow{2}{*}{$\begin{array}{l}\text { Original } \\
\text { Low Flow }\end{array}$} & - & & & \\
\hline & & - & $\# N / A$ & $\# N / A$ & $\# N / A$ \\
\hline & Aerator & 3 & & & $10 \%$ \\
\hline \multirow[t]{3}{*}{ Shower } & \multirow{2}{*}{$\begin{array}{l}\text { Original } \\
\text { Low Flow }\end{array}$} & - & & & \\
\hline & & - & $\# N / A$ & $\# N / A$ & $\# \mathbf{N} / \mathbf{A}$ \\
\hline & Aerator & 2 & & $16 \%$ & $15 \%$ \\
\hline \multirow[t]{2}{*}{ Clothes Washer } & \multirow{2}{*}{$\begin{array}{l}\text { Original } \\
\text { Efficient }\end{array}$} & - & & & \\
\hline & & 1 & & & \\
\hline \multirow[t]{3}{*}{ Toilet } & \multirow{3}{*}{$\begin{array}{l}\text { Original } \\
\text { Low Flow } \\
\text { Dual Flush }\end{array}$} & - & & & \\
\hline & & - & $\# \mathbf{N} / \mathbf{A}$ & $\# \mathbf{N} / \mathrm{A}$ & $\# N / A$ \\
\hline & & & & & $5 \%$ \\
\hline
\end{tabular}


With the further addition of grey water and black water systems we can see noticeable changes in overall ROI.

Table 20: Appendix: Overall

\begin{tabular}{ll} 
Appliance & Type \\
\hline Kitchen Sink & Original \\
& Low Flow \\
& Aerator \\
\hline Dishwasher & Original \\
& Efficient \\
\hline \multirow{3}{*}{ Other Sink } & Original \\
& Low Flow \\
& Aerator \\
\hline \multirow{3}{*}{ Shower } & Original \\
& Low Flow \\
&
\end{tabular}

\section{Clothes Washer Original}

\begin{tabular}{ll} 
& Efficient \\
\hline Toilet & Original \\
& Low Flow \\
& Dual Flush
\end{tabular}

Landscaping Type

Amount
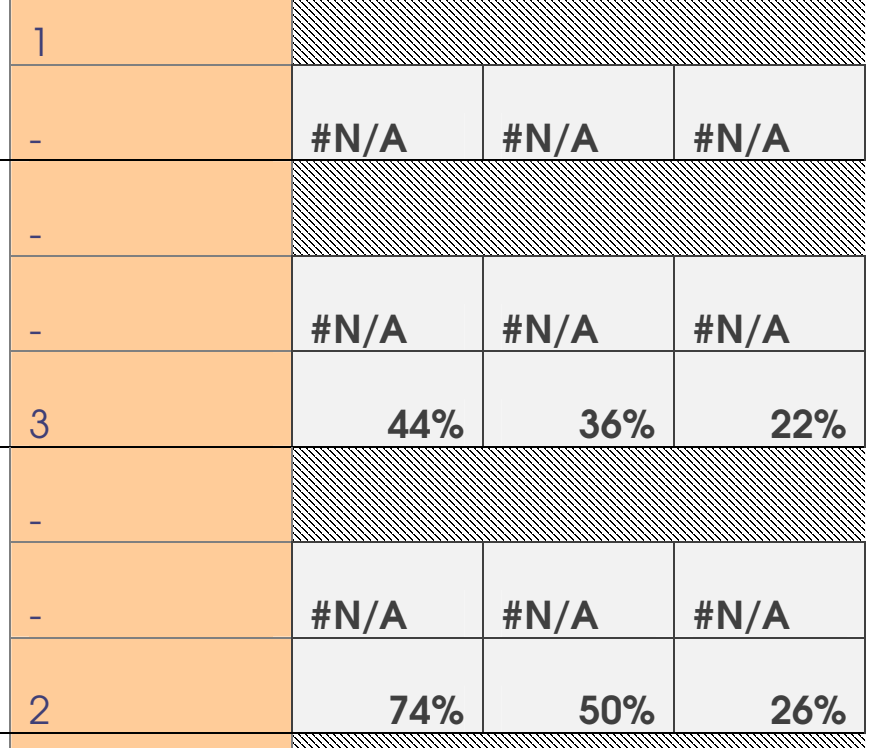

1

\#N/A

Use

(Gal/Day) 
Black Water

Treatment

Appliance only overall ROI

Table 21: Appendix: Alternate ROI

\begin{tabular}{|c|r|r|r|}
\hline Initial Cost & \multicolumn{1}{|c}{ Year } & 10 Year & 30 Year \\
\hline$\$ 87.00$ & $31.19 \%$ & $30.26 \%$ & $20.01 \%$ \\
\hline
\end{tabular}

Advanced systems overall ROI

\begin{tabular}{|l|r|r|r|}
\multicolumn{1}{|c|}{ Initial Cost } & \multicolumn{1}{c}{$\mathbf{5}$ Year } & \multicolumn{1}{c}{10 Year } & \multicolumn{1}{c|}{30 Year } \\
\hline \begin{tabular}{|l|l|}
$\$$ \\
649.84
\end{tabular} & $15.17 \%$ & $22.05 \%$ & $17.43 \%$ \\
\hline
\end{tabular}




\section{Bibliography}




\section{Bibliography}

Adams, Sam, and Susan Anderson. "Rainwater harvesting." City of Portland, Oregon. N.p., n.d. Web. 8 Sept. 2011. <http://www.portlandonline.com/bps/index.cfm?c=ecbbd\&a=bbehfa .

"Advanced Treatment Systems." Orenco Systems, Inc. N.p., n.d. Web. 9 Sept. 2011. <http://www.orenco.com/sales/choose_a_system/advanced_treatment_syste $\mathrm{ms} /$ index.cfm>.

"Aerated and advanced wastewater treatment systems." Level. N.p., n.d. Web. 9 Sept. 2011. <http://www.level.org.nz/water/wastewater/on-site-wastewatertreatment/aerated-and-advanced-wastewater-treatment-systems/>.

Anua. "Blackwater Treatment as Part of a Water Reuse Plan." Anua. N.p., 19 July 2011. Web. 9 Sept. 2011 . <http://blog.anua-us.com/blog/bid/59098/BlackwaterTreatment-as-Part-of-a-Water-Reuse-Plan>.

"Aqua2use Grey Water Systems." Greywater. N.p., n.d. Web. 8 Aug. 2011. <http://www.waterwisegroup.com/buy-now.htmls.

BNet for CBS. "SURVEY: Average Price of Water on the Increase." BNET. N.p., 14 Aug. 2006. Web. 26 Jan. 2011. <http://findarticles.com/p/articles/mi_m5CNK/is_2006_August_14/ai_n24991674/ $>$.

Barber, Nancy L.. "Summary of Estimated Water Use in the United States in 2005." USGS Publications Warehouse. N.p., 27 Oct. 2009. Web. 14 Feb. 2011. $<\mathrm{http}: / /$ pubs.usgs.gov/fs/2009/3098/>.

"Blackwater and Water Recycling." Water Filtering. N.p., n.d. Web. 9 Sept. 2011. $<$ http://www.waterfiltering.com/conservation/blackwater-and-waterrecycling.html>.

Brandes, Marek. "Characteristics of Effluents from Gray and Black Water Septic Tanks." Journal (Water Pollution Control Federation) 50.11 (1978): 2547-2559 . JSTOR.org. Web. 6 Nov. 2010.

"CA-New Standard." Graywater.org. N.p., 29 Apr. 2009. Web. 8 Aug. 2011. $<$ http://graywater.org/graywater-policy/new-standard>.

CBIA. "Water Use in the California Residential Home." ConSol 1 (2010): n. pag. California Building Industry Association. Web. 15 June 2011.

"California City and County Sales and Use Tax Rates - Cities, Counties and Tax Rates." California State Board of Equalization. N.p., 1 July 201 1. Web. 2 Aug. 2011. <http://boe.ca.gov/cgi-bin/rates.cgi?LETTER=O\&LIST=COUNTY>.

"California Graywater Code." Oasis Design. N.p., n.d. Web. 8 Aug. 2011. <http://www.oasisdesign.net/greywater/law/california/currentcode/>.

Calomiris, John J., and Keith A. Christman. "How does chlorine added to drinking water kill bacteria and other harmful organisms? Why doesn't it harm us?." Scientific American. N.p., 4 Mar. 1998. Web. 7 Sept. 2011. $<$ http://www.scientificamerican.com/article.cfm?id=how-does-chlorine-addedt-1998-05-04>.

Carpenter, Susan. "Australian water crisis offers clues for California (Updated)." Los Angeles Times. N.p., 15 Jan. 2010. Web. 5 Oct. 2010. <http://latimesblogs.latimes.com/greenspace/2010/01/australian-water-crisis- 
provides-clues-for-california-at-gday-usa.html>. Comparison of water crisis in Australia to California.

"Census Bureau." State and Local Governments - Expenditures for Public Works: 2000 to 2007. N.p., n.d. Web. 13 June 2011.

<WWW.census.gov/compendia/statab/2011/tables/11s0436.pdf>.

"Chem Feed Systems." BudgetWater. N.p., n.d. Web. 7 Sept. 2011.

<http://www.budgetwater.com/chem_feed_systems.htm\# Inside_the_well_chlori ne_feeder>.

Clancy, Heather. "Biggest sustainability spenders come from high-tech, consumer goods and energy." SmartPlanet. N.p., 7 Oct. 2010. Web. 13 Oct. 2010. <http://www.smartplanet.com/business/blog/business-brains/research-biggestsustainability-sector-spenders-are-high-tech-consumer-goods-andenergy/10696/>. Money spent on sustainable corporate.

Cohen, Yoni. "A new desalination method for California water woes?." Los Angeles Times. N.p., 26 Feb. 2010. Web. 5 Oct. 2010. <http://latimesblogs.latimes.com/greenspace/2010/02/the-los-angelesdepartment-of-water-and-powers-rationing-program-has-reduced-the-cityswater-use-to-an-18-year-low-but.html>. New desalination method for California.

Collins, Clint. Phone interview. 16 Mar. 2011.

"Cost of Drip Irrigation." CostHelper.com. N.p., n.d. Web. 21 June 2011. <http://www.costhelper.com/cost/home-garden/drip-irrigation.htmls.

"Cost of a Sprinkler System." CostHelper.com. N.p., n.d. Web. 21 June 2011. <http://www.costhelper.com/cost/home-garden/sprinklers.html>.

"Current Inflation." InflationData. N.p., n.d. Web. 15 June 2011. <http://inflationdata.com/inflation/Inflation_Rate/CurrentInflation.asp>.

Dixon, A. M., D. Butler, and A. Fewkes. "Guidelines for Greywater Re-Use: Health Issues." Water and Environment Journal 13.5 (1999): 322-326. Print. Grey water reuse.

Dixon, Jill, and Joan Buhrman. "Infrastructure Report Card 2005." American Society of Civil Engineers (ASCE). N.p., n.d. Web. 13 June 2011. $<$ http://apps.asce.org/reportcard/2005/page.cfm?id=108>.

"Drinking Water Contaminants." US EPA. N.p., 11 Jan. 201 1. Web. 15 Apr. 2011. $<$ http://water.epa.gov/drink/contaminants/index.cfm>.

EPA. "Overview." Community Water System Survey 20001 (2002): 18. EPA.org. Web. 13 June 2011.

EPA. "The Clean Water and Drinking Water Infrastructure Gap Analysis." U.S. Environmental Protection Agency 1 (2002): n. pag. EPA.org. Web. 13 June 2011.

Earth Craft. "Rainwater Harvesting." Earth Craft. N.p., 5 Mar. 2002. Web. 31 Jan. 2011. $<$ www.earthcrafthouse.com/documents/factsheets/27_rainwater-recoveryv2.pdf>.

"Earth-Smart Design." IslandWood. N.p., n.d. Web. 9 Sept. 2011. <http://islandwood.org/about/history_of_islandwood/sustainabledesign>.

"EarthCraft House 2011 Technical Guidelines." EarthCraft. N.p., n.d. Web. 17 Nov. 2011. <earthcraft.org/images/stories/documents/guidelines-4-26-201 1.pdf>.

"Emergency Graywater Code." HCD.ca.gov. N.p., 30 June 2009. Web. 2 Aug. 2011. <www.hcd.ca.gov/codes/shl/Preface_ET_Emergency_Graywater.pdf>.

Emily, and Mandy. "Water Infrastructure." Pulitzer Center. N.p., 14 Jan. 2011. Web. 5 
June 2011 . <http://pulitzercenter.org/education/student-reporting/waterinfrastructures.

"Environmental Issues: People's Views and Practices, Mar 2007." Australian Bureau of Statistics. N.p., 6 Dec. 2007. Web. 26 Jan. 2011.

<http://www.abs.gov.au/ausstats/abs@.nsf/mediareleasesbyReleaseDate/F1E6 78792E29EED7CA2573A80017F241?OpenDocument>.

Errson, Ole. "Rainwater Harvesting and Purification System." Harvesting Water. N.p., n.d. Web. 8 Sept. 2011. <http://www.harvestingwater.com/rainwatr.htm>.

Escobar, Isabel, and Andrea Schai^ ${ }^{\wedge}$ fer. Sustainable water for the future water recycling versus desalination. Amsterdam: Elsevier Science, 2009. Print.

Farrell, Mary, Liz Van der Hoven, and Tedann Olsen. "Vermont Rest Area Replaces Septic Tanks With Green Wastewater Treatment System." Septic Tank Info. N.p., n.d. Web. 9 Sept. 2011 . <http://septictankinfo.com/living_machine.shtml>.

"Frequently Asked Questions." Greywater Action. N.p., n.d. Web. 8 Aug. 2011. <http://greywateraction.org/fags/greywater-recycling $>$.

Fuller, Rich. "What Is Black Water Holding Tank Treatment." EzineArticles. N.p., 5 Mar. 2007. Web. 9 Sept. 2011 . <http://ezinearticles.com/?What-ls-Black-WaterHolding-Tank-Treatment\&id=476613>.

Gelt, Joe. "Graywater and Rainwater use." University of Arizona. N.p., n.d. Web. 8 Sept. 2011. <http://ag.arizona.edu/azwater/arroyo/071 rain.html>.

Gottlieb, Jeff, and Nicole Santa Cruz. "Rationing cuts L.A. water usage to the lowest level in 18 years." The Los Angeles Times. N.p., 5 Dec. 2009. Web. 5 Oct. 2010. <http://articles.latimes.com/2009/dec/05/local/la-me-water5-2009dec05>. California water crisis.

"Grey water - recycling water at home." Better Health Channel. N.p., 27 July 201 1. Web. 8 Aug. 2011. <http://www.betterhealth.vic.gov.au/bhcv2/bhcarticles.nsf/pages/Grey_water _-_recycling_water_at_homes.

"Greywater Disposal Systems." The Natural Home Building Source. N.p., n.d. Web. 27 July 2011. <https://www.thenaturalhome.com/greywater.html>.

Herman, Glenda M., and Gregory D. Jennings. "Home Drinking Water Treatment Systems." North Carolina State University. N.p., n.d. Web. 7 Sept. 2011. <http://www.bae.ncsu.edu/programs/extension/publicat/wqwm/he419.htmls.

Hinrichsen, Don, and Bryant Robey. "The Global Challenge." ActionBioscience. N.p., n.d. Web. 15 Sept. 2011. $<$ http://www.actionbioscience.org/environment/hinrichsen_robey.html>.

Hinrichsen, Don, and Bryant Robey. "Population and the Environment: The Global Challenge." ActionBioscience. N.p., n.d. Web. 4 Dec. 2011. $<\mathrm{http}: / /$ www.actionbioscience.org/environment/hinrichsen_robey.html?fb_pag e_id $=10001867493 \&>$.

"Household Water Efficiency: Faucets." Water Wiki. N.p., 18 Dec. 2008. Web. 17 June 2011. <sogweb.sog.unc.edu/Water/index.php/Household_Water_Efficiency:_Faucets>

"How Much do Composting Toilets Costs?." Toilet Composting Information. N.p., 25 June 2009. Web. 9 Sept. 2011. <http://toilet-composting.com/how-much-do- 
composting-toilets-cost/>.

"Irvine Real Estate \& Irvine Homes For Sale." Trulia. N.p., n.d. Web. 3 Apr. 2011. $<\mathrm{http}: / /$ www.trulia.com/CA/Irvine/\# for_sale/Irvine,CA/2p_beds/600000700000_price/new_homes_It/>.

"Irvine Real Estate Market Data, Trends \& Statistics." OC Exclusives. N.p., 5 Apr. 2011. Web. 5 Apr. 2011 . <http://www.ocexclusives.com/irvine-real-estate-marketdata.php>.

"Irvine, CA Precipication." Weather.com. N.p., n.d. Web. 8 Sept. 2011. $<$ www.weather.com/weather/wxclimatology/monthly/graph/USCA0517>.

Jefferson, B., A. Palmer, P. Jeffrey, R. Stuetz, and S. Judd. "Grey water characterisation and its impact on the selection and operation of technologies for urban reuse." Water Science and Technology 50.2 (2004): 157 - 164. Washington.edu. Web. 6 Nov. 2010.

Kenny, Joan, Nancy Barber, Susan Hutson, Kristin Linsey, John Lovelace, and Molly Maupin. "Estimated use of water in the United States in 2005." U.S. Geological Survey Circular 1344 (2009): 19-22, 43, 44. USGS. Web. 24 Jan. 2011. Water Statistics.

Kibert, Charles J.. Sustainable Construction: Green Building Design and Delivery. 2 ed. New York, NY: Wiley, 2007. Print.

Koomey, Dunham, and Lutz. "The Effect of Efficiency Standards on Water Use and Water Heating Energy Use in the U.S.: A Detailed End-use Treatment ." Energy Source Builder Dec. 1995: n. pag. Oikos. Web. 14 Feb. 2011.

Krishna, Dr. Hari J.. "The Texas Manual on Rainwater Harvesting." Texas Water Development Board 3 (2005): n. pag. Texas Water Development Board. Web. 8 Sept. 2011.

Lance, Jennifer. "Toilet to Tap: Orange County Turning Sewage Water into Drinking Water â€" Blue Living ldeas." Blue Living Ideas. N.p., 14 Mar. 2009. Web. 9 Sept. 2011. <http://bluelivingideas.com/2009/03/14/toilet-to-tap-orange-countyturning-sewage-water-into-drinking-water/>.

"Leading Compost Toilet Information and Advice." Compst Junkie. N.p., n.d. Web. 9 Sept. 2011. <http://www.compostjunkie.com/compost-toilet.html>.

Lehr, Valentine. "Gray Water Systems." Heating/Piping/Air Conditioning None (1987): n. pag. Global Engineering Confrence. Web. 5 Nov. 2010.

McMaster-CARR. "Catalog." McMaster-CARR 113 (2007): 1914-1943. Print.

McWirther, Cameron. "Extreme Drought Grips Parts of South, Midwest - WSJ.com." The Wall Street Journal. N.p., 20 Oct. 2010. Web. 24 Jan. 2011. <http://online.wsj.com/article/SB 10001424052702304011604575564520488798994. html?mod=WSJ_hps_LEFTWhatsNews>.

Mitchell, V.G., R.G. Mein, and T.A. McMahon. "Modelling the urban water cycle." Environmental Modelling \& Software 16.7 (2001): 615. Elsevier. Web. 6 Nov. 2010.

Mone, John. "Ultraviolet (UV) Water Purifiers." HarvestH2o.com. N.p., n.d. Web. 8 Sept. 2011. <http://www.harvesth2o.com/uv.shtml>.

Morrison, Taylor. "BHI Plan Viewer." Taylor Morrison Homes. N.p., n.d. Web. 3 Apr. 2011. $<\mathrm{http}$ ://www.taylormorrison.com/IFViewer/BHIPlanViewer.aspx?planType=p\&pla $\mathrm{nID}=5020>$.

"Mortgage Rates." Interest.com. N.p., 2 Aug. 2011. Web. 2 Aug. 2011. 
$<\mathrm{http}: / / \mathrm{www}$.interest.com/mortgage/rates $/$ ?prods=1\&loan=680000\&market=973 \&points=Zero\&perc $=20>$.

Muller, Dominique, and Nicolas Favet. Sustainable architecture and urbanism: concepts, technologies, examples. Basel: Birkhauser, 2002. Print.

"Nitrogen...too much or too little goes a long way. ." Drinking Water Filters. N.p., n.d. Web. 14 Apr. 2011.

$<$ http://www.freedrinkingwater.com/water_quality/quality 1/1-lot-or-littlenitrogen-goes-a-long-way.htm>.

"On-site wastewater treatment." Level. N.p., n.d. Web. 9 Sept. 2011. <http://www.level.org.nz/water/wastewater/on-site-wastewater-treatment/>.

Perlman, Howard. "The Water Cycle: Freshwater storage, from USGS Water Science for Schools." USGS Georgia Water Science Center - Home page. N.p., 14 Dec. 2010. Web. 24 Jan. 2011. <http://ga.water.usgs.gov/edu/watercyclefreshstorage.html>.

"Primer for Municipal Wastewater Treatment Systems." EPA.gov. N.p., n.d. Web. 13 Apr. 2011. <www.epa.gov/owm/primer.pdf>.

Pushard, Doug. "Filtration and purification." HarvestH2o.com. N.p., n.d. Web. 8 Sept. 2011. <http://www.harvesth2o.com/filtration_purification.shtml>.

"Residential." Irvine Ranch Water District. N.p., n.d. Web. 8 Aug. 2011. $<$ http://www.irwd.com/alwayswatersmart/residential.htmls.

Russo, Michele A., Catlin Shaughnessy, and Scott Lewis. Commercial \& institutional green building: green trends driving market change. New York, NY: Mcgraw-Hill Construction ;, 2008. Print.

SBL. "Residential Water Usage Explained I SaveBuyLive." SaveBuyLive. N.p., 10 June 2009. Web. 14 Feb. 2011. <http://www.savebuylive.com/2009/06/10/residentialwater-usage-explained/>.

"Safe Use of Household Greywater." New Mexico State University. N.p., n.d. Web. 29 Nov. 2010. <http://aces.nmsu.edu/pubs/_m/m-106.html>.

Schoch, Deborah. "California Water Rationing." Los Angeles Times. N.p., 2 May 2008. Web. 21 Nov. 2011. <http://articles.latimes.com/2008/may/02/local/mesnowpack2>.

Slessor, Catherine, and John Linden. Eco-tech: sustainable architecture and high technology. (First paperback ed. London: Thames \& Hudson, 2001. Print.

"Standard Pumping Systems." Orenco Systems, Inc.. N.p., n.d. Web. 9 Sept. 2011. <http://www.orenco.com/sales/choose_a_system/effluent_pumping_systems/in dex.cfm>.

"State and Local Government Finances by Level of Government and by State: 2005-06." U.S. Census Bureau. N.p., 1 July 2008. Web. 13 June 2011. $<$ www.census.gov/govs/estimate/0600ussl_1.html>.

Steele, James. Sustainable architecture: principles, paradigms, and case studies. New York: McGraw-Hill, 1997. Print.

Stein, Benjamin, John S. Reynolds, Walter T. Grodzik, and Alison G. Kwok. Mechanical and Electrical Equipment for Buildings. 10th ed. New York: McGraw-Hill, 2009. Print.

"Take-Home-Pay Calculator." Calculator.net. N.p., n.d. Web. 2 Aug. 2011. <http://www.calculator.net/take-home-pay- 
calculator.html?cannualincome $=1$ 15000\&cpayfrequency=Weekly\&cfilestatus $=$ MarriedJoint\&callowance $=2 \&$ cdeduction $=500 \&$ cstatetax $=7.25 \&$ ccitytax $=7.75 \&$ cadditionat $1=$ no $\& x=81 \& y=6>$.

Thomas, Justin. "The Best Kitchen Faucet Aerators >> MetaEfficient Review."

MetaEfficient. N.p., 30 Mar. 2008. Web. 17 June 2011.

<http://www.metaefficient.com/bathroom-products/kitchen-faucetaerator.html>.

"U.S. Wastewater Treatment." Center for Sustainable Systems. N.p., n.d. Web. 13 Apr. 2011. <css.snre.umich.edu/css_doc/CSSO4-14.pdf>.

US Census Bureau. "Irvine city, California." American FactFinder. N.p., n.d. Web. 3 Apr. 2011.

<http://factfinder.census.gov/servlet/ACSSAFFFacts?_event=Search\&geo_id=\&_ geoContext=\&_street=\&_county=irvine\&_cityTown=irvine\&_state $=04000 U S 06 \&$ zi $\mathrm{p}=$ \&_lang=en\&_sse=on\&pctxt=fph\&pgsl=010>.

"Urbanization/water quality: Nitrogen." USGS Georgia Water Science Center. N.p., 8

Feb. 2011. Web. 15 Apr. 2011.

<http://ga.water.usgs.gov/edu/urbannitrogen.html>.

WRCC. "Environmental Analysis." City of Irvine. N.p., n.d. Web. 20 Dec. 2011. $<w w w$.cityofirvine.org/civica/filebank/blobdload.asp?BloblD=17716>.

"Wage Garnishment Calculator." Money-zine.com. N.p., n.d. Web. 2 Aug. 2011. $<\mathrm{http}$ //www.money-zine.com/Calculators/Loan-Calculators/WageGarnishment-Calculator/s.

"Water Facts." Water.org. N.p., n.d. Web. 5 Nov. 2010. <http://water.org/learn-aboutthe-water-crisis/facts/>.

"Water Supply." Irvine Ranch Water District. N.p., n.d. Web. 21 June 2011. <http://www.irwd.com/your-water/water-supply.htmls.

"WaterSense." US Environmental Protection Agency. N.p., 17 June 201 1. Web. 21 June 2011. <http://www.epa.gov/WaterSense/products/showerheads.html>.

"Worrell Water Technologies." Worrell Water Technologies. N.p., n.d. Web. 20 Dec. 2011. $<\mathrm{http}$ ://worrellwater.com/>.

kerryg. "Living Machines." kerryg on HubPages. N.p., n.d. Web. 9 Sept. 2011. <http://kerryg.hubpages.com/hub/Living-Machines>.

piping, eliminating the planning constraints of the sewage system underground, infrastructure, and social considerations. "The Benefits of Composting Toilets." Composting Toilet World. N.p., n.d. Web. 9 Sept. 2011. <http://compostingtoilet.org/compost_toilets_explained/the_benefits_of_comp osting_toilets/index.php>.

MLA formatting by BibMe.org. 